\title{
Bodemleven
}

\section{BoBi RIVM}

\section{NemadecideGeo}

Aaltjesschema

Pachtvoor-

waarden $\mathrm{NH}$
Bodemconditie

Score
Delphy Bodemschat

Bodem Stuctuur

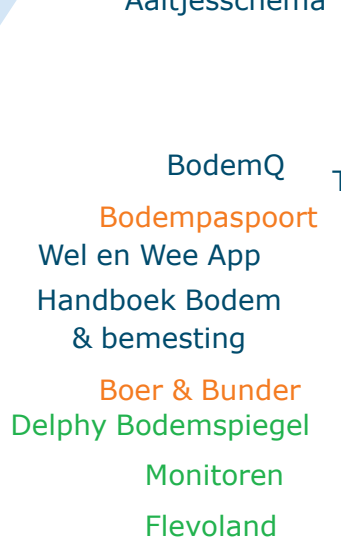

Chemische

bodem-

vruchtbaarheid

\section{Instrumenten voor Duurzaam Bodembeheer}

\section{Een overzicht}

Auteur | Leendert Molendijk, Pieter de Wolf en Marie Wesselink

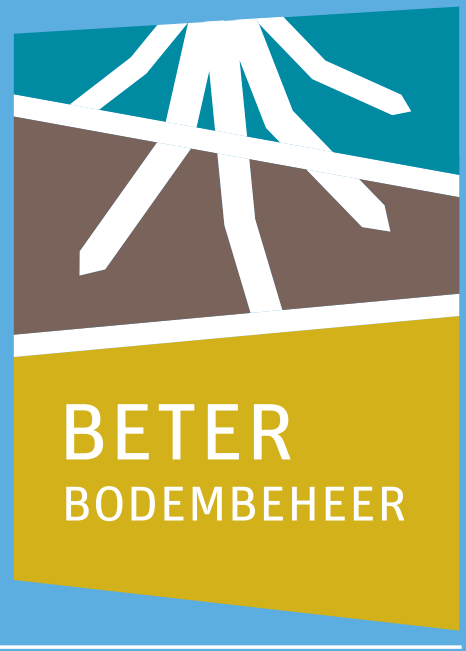




\title{
Instrumenten voor Duurzaam Bodembeheer
}

\author{
Een overzicht
}

Leendert Molendijk, Pieter de Wolf en Marie Wesselink

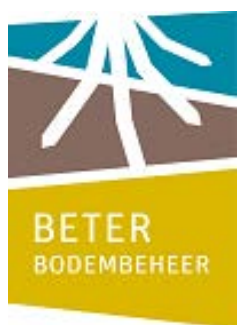

Dit onderzoek is in opdracht van PPS Duurzaam Bodembeheer uitgevoerd door de Stichting Wageningen Research (WR), business unit Open Teelten.

WR is een onderdeel van Wageningen University \& Research, samenwerkingsverband tussen Wageningen University en de Stichting Wageningen Research. 
Molendijk, L.P.G., P.L. de Wolf en M. Wesselink, 2018. Instrumenten voor Duurzaam Bodembeheer; Een overzicht. Wageningen Research, Rapport WPR-740.

Dit rapport is gratis te downloaden op: https://doi.org/10.18174/455058

\section{Samenvatting}

Het rapport geeft een overzicht van 32 instrumenten voor duurzaam bodembeheer, beschikbaar voor Nederlandse gebruikers in de akkerbouw en/of melkveehouderij. Een aantal richt zich op het meten van bodemkwaliteit, een deel is beslissingsondersteunend/adviserend en enkele instrumenten zijn gemaakt om het bodembeheer te verantwoorden. De meeste instrumenten werken aan de (chemische) bodemvruchtbaarheid, naast een groep instrumenten die chemische, fysische en/of biologische aspecten combineert. Slechts een klein aantal richt zich uitsluitend op fysische of biologische bodemkwaliteit.

Eén van de doelen van dit rapport is dat het lezers helpt de weg te vinden naar de instrumenten die voor hen meerwaarde bieden. De verwachting is dat ook op bodemgebied er in hoog tempo meer applicaties beschikbaar komen, variërend van een eenvoudige één-vraag één-antwoord app tot de integrale Decision Support Systems toegesneden op perceelsniveau. Dit rapport kan ontwikkelaars en aanbieders helpen om hun instrumenten goed te positioneren, samenwerking te zoeken en losse tools beter te integreren.

Daarnaast roepen we alle betrokkenen op om aandacht te besteden aan de benodigde kennis van gebruikers, zodat instrumenten effectief gebruikt kunnen worden om het bodembeheer te verbeteren. Daar ligt wat ons betreft een gezamenlijke verantwoordelijkheid van overheid, sector en bedrijfsleven: door regievoering kunnen middelen voor ontwikkeling van instrumenten effectiever worden ingezet en in combinatie met kennisontwikkeling bij gebruikers kunnen ontwikkelde instrumenten beter en sneller worden toegepast.

Trefwoorden: bodembeheer, bodemkwaliteit, instrumenten, tools

(c) 2017 Wageningen, Stichting Wageningen Research, Wageningen Plant Research, Business unit Praktijkonderzoek AGV, Postbus 430, 8200 AK Lelystad; T 03202911 11; www.wur.nl/plant-research

KvK: 09098104 te Arnhem

VAT NL no. 8113.83.696.B07

Stichting Wageningen Research. Alle rechten voorbehouden. Niets uit deze uitgave mag worden verveelvoudigd, opgeslagen in een geautomatiseerd gegevensbestand, of openbaar gemaakt, in enige vorm of op enige wijze, hetzij elektronisch, mechanisch, door fotokopieën, opnamen of enige andere manier zonder voorafgaande schriftelijke toestemming van Stichting Wageningen Research.

Stichting Wageningen Research is niet aansprakelijk voor eventuele schadelijke gevolgen die kunnen ontstaan bij gebruik van gegevens uit deze uitgave.

Rapport WPR-740 


\section{Inhoud}

Summary $\quad 5$

$\begin{array}{ll}\text { Samenvatting } & 7\end{array}$

$1 \quad$ Inleiding $\quad 9$

$\begin{array}{lll}1.1 & \text { Selectiecriteria } & 9\end{array}$

1.2 Opbouw van het rapport $\quad 9$

$\begin{array}{ll}\text { Duurzaam bodembeheer: het kader } & 11\end{array}$

$\begin{array}{ll}\text { Een overzicht van de instrumenten } & 13\end{array}$

3.1 Meten \& Monitoren $\quad 14$

3.1.1 Bodembiologische Indicatoren (Bobi) 14

$\begin{array}{ll}3.1 .2 \text { Bodemconditiescore } & 14\end{array}$

3.1.3 Delphy bodemspiegel $\quad 15$

3.1.4 Monitoring Flevoland (door studenten van de Aeres Hogeschool) 15

$\begin{array}{ll}3.1 .5 \text { Verisscan } & 16\end{array}$

3.2 Management \& Advies $\quad 16$

3.2.1 Aaltjesschema 16

$\begin{array}{ll}3.2 .2 \text { Akkerweb } & 17\end{array}$

$\begin{array}{ll}3.2 .3 \text { BodemQ (NMI) } & 18\end{array}$

3.2.4 Bodemverkenner 18

3.2.5 Delphy bemestingsplan 19

3.2.6 Delphy Bodemschat $\quad 19$

3.2.7 Demeter tool 20

$\begin{array}{ll}3.2 .8 \text { DLV mijNperceel.nl } & 20\end{array}$

3.2.9 Handboek Bodem en Bemesting 20

3.2.10Hydrometra ( 6 watermodules in KringloopWijzer) 21

3.2.11Mest en Mineraal (Agrifirm via Akkerweb) 22

3.2.12Mijn percelen. $\mathrm{nl}$, bemestingswijzer en TerraDecide (Eurofins) 22

3.2.13Mineralisatietool KennisAkker $\quad 22$

3.2.14NDICEA $\quad 23$

3.2.15NemaDecideGeo $\quad 23$

3.2.16Nutrinorm bemestingsplanner $\quad 24$

3.2.17Organische stof rekentool $\quad 24$

3.2.18Slim Bemesten $\quad 25$

3.2.19Sluiten mineralenkringlopen (NMI) $\quad 25$

$\begin{array}{ll}3.2 .20 T r i j n t j e & 26\end{array}$

$\begin{array}{ll}3.2 .21 \text { Wel en Wee app } & 26\end{array}$

$\begin{array}{lll}3.3 & \text { Verantwoording } & 27\end{array}$

3.3.1 Bodempaspoort $\quad 27$

3.3.2 Boer \& Bunder $\quad 28$

3.3.3 Label Duurzaam Bodembeheer 28

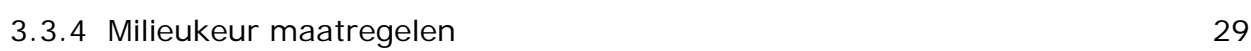

3.3.5 Pachtvoorwaarden provincie NH - uitgifte van eigen pachtgrond onder $\begin{array}{ll}\text { duurzaamheidscertificering } & 29\end{array}$

3.3.6 Veldleeuwerik Duurzaamheidsplan- bodemmaatregelen 30

$\begin{array}{lll}3.4 & \text { Overige initiatieven } & 30\end{array}$

3.4.1 SoilCares 30

3.4.2 Soil Health Index 31

3.4.3 Diverse onderzoekstools 31 
4.1 Analyse

33

4.2 Reflectie

37 


\section{Summary}

Soil management is a hot topic in agriculture: more and more arable and dairy farmers are actively improving their soil management. To support this, various actors are developing and providing tools and instruments to monitor and improve soil quality or to justify soil management to value chain actors or land renters.

This report presents an overview of currently (spring 2017) available soil management instruments. Because of the ongoing development and release of new instruments, the overview is just a snapshot. The selection criteria for this overview: the instrument uses data to provide insight or advice to the user; the instrument is available (spring 2017) for users or becomes available within a year; the tool is available for Dutch users in arable and/or dairy farming. The tools are divided into three categories, based on their functionality. Those categories are: measuring $\&$ monitoring, management $\&$ advice and accountability. All the criteria together result in the following list of 32 instruments ${ }^{1}$ :

Measuring \& Monitoring:

- Bodembiologische indicatoren RIVM (BoBi)

- Bodemconditiescore

- Delphy bodemspiegel

- Monitoring Flevoland

- Verisscan

Management \& Advice:

- Aaltjesschema

- Akkerweb

- BodemQ (NMI)

- Bodemverkenner

- Delphy bemestingsplan

- Delphy bodemschat

- Demeter tool

- DLV mijNperceel.nl

- Handboek Bodem en Bemesting

- Hydrometra (6 Watermodules Kringloopwijzer)

- Mest en Mineraal (Agrifirm)

- MijNpercelen.nl, bemestingswijzer en TerraDecide (Eurofins)

- Mineralisatietool op KennisAkker

- NDICEA

- NemadecideGeo

- Nutrinorm bemestingsplanner

- Organische stof rekentool

- Slim Bemesten

- $\quad$ Sluiten mineralenkringlopen (NMI)

- $\quad$ Trijntje

- Wel en Wee app

Accountability:

- Bodempaspoort

- Boer \& Bunder

- Label duurzaam bodembeheer

- Milieukeur maatregelen

- Pachtvoorwaarden provincie NH: duurzaamheidscertificering voor pachtgronden

- Veldleeuwerik Duurzaamheidsplan

\footnotetext{
${ }^{1}$ the names are kept in Dutch, to support internet search. Several websites also have an English version.
} 
An inventory during the symposium 'Beter Bodembeheer - de diepte in' (Improved soil management in depth', April 6. 2017) showed that the use of most instruments is limited. Many instruments are developed from a commercial perspective, others are evolved as a project output. In several cases, these project-based instruments are not maintained anymore since the end of the project. Moreover, there is clearly no central coordination for the development of instruments.

Most instruments approach soil quality from a single (chemical) soil fertility perspective, although quite some instruments have a more integrative approach (combination of chemical, physical and biological aspects). Only few instruments are dedicated to biological or physical soil quality issues. Regarding the soil data used, many instruments make use of default data, although the use of real farm- and field specific data is becoming more important for users.

Although an integrative approach of soil quality is important for single instruments, it is also relevant to work on the integration of specialised instruments. Users would like to see more interaction between instruments both at the input side, so users don't have to fill in the same data in various instruments, but also at the output side, to avoid conflicting outcomes and advices.

As far as we are concerned, there is a joint responsibility of Government, industry and business to stimulate initiatives, to organize cooperation and the efficient use of resources. In addition, we call on all parties concerned to pay attention to the knowledge of end users, so that instruments can be used effectively to improve soil management. Tools developed in combination with knowledge enhancement will be applied more effective and faster. 


\section{Samenvatting}

Bodembeheer is een actueel onderwerp in de landbouw: steeds meer akkerbouwers en melkveehouders zijn actief bezig met het verbeteren van hun bodembeheer. Om hierin te kunnen ondersteunen ontwikkelen allerlei organisaties en partijen diverse tools en instrumenten die onder andere helpen bij het bepalen en verbeteren van de bodemkwaliteit of ook bij het verantwoorden van het bodembeheer.

In dit rapport wordt een overzicht gepresenteerd van de huidige (voorjaar 2017) beschikbare bodemkwaliteitsinstrumenten. Gezien het feit dat er continu nieuwe instrumenten in ontwikkeling zijn is dit overzicht slechts een momentopname. De volgende criteria zijn gebruikt voor opname van een tool in dit overzicht: Het instrument komt op basis van data tot een resultaat, in de vorm van inzicht of een advies voor de gebruiker; Het instrument is momenteel (voorjaar 2017) of binnen een jaar beschikbaar voor gebruik; Het instrument is beschikbaar voor Nederlandse gebruikers in de akkerbouw en/of melkveehouderij. Om het overzicht zo volledig mogelijk te maken is gebruik gemaakt van kennis van experts. De gevonden instrumenten zijn ingedeeld in drie categorieën, op basis van hun functionaliteit; ze zijn ofwel een ondersteuning bij het meten of monitoren van de bodemkwaliteit, ofwel ze ondersteunen bij management en geven advies, of ze zijn bedoeld als verantwoordingsinstrument. Aan de hand van deze criteria is de volgende lijst van 32 instrumenten tot stand gekomen:

Meten \& Monitoren:

- Bodembiologische indicatoren RIVM (BoBi)

- Bodemconditiescore

- Delphy bodemspiegel

- Monitoring Flevoland

- Verisscan

Management \& Advies:

- Aaltjesschema

- Akkerweb

- BodemQ (NMI)

- Bodemverkenner

- Delphy bemestingsplan

- Delphy bodemschat

- Demeter tool

- DLV mijNperceel.nl

- Handboek Bodem en Bemesting

- Hydrometra (6 Watermodules Kringloopwijzer)

- Mest en Mineraal (Agrifirm)

- MijNpercelen.nl, bemestingswijzer en TerraDecide (Eurofins)

- Mineralisatietool op KennisAkker

- NDICEA

- NemadecideGeo

- Nutrinorm bemestingsplanner

- Organische stof rekentool

- Slim Bemesten

- Sluiten mineralenkringlopen (NMI)

- Trijntje

- Wel en Wee app

Verantwoording:

- Bodempaspoort 
- $\quad$ Boer \& Bunder

- Label duurzaam bodembeheer

- Milieukeur maatregelen

- Pachtvoorwaarden provincie NH: duurzaamheidscertificering voor pachtgronden

- Veldleeuwerik Duurzaamheidsplan

Uit een inventarisatie op de Themadag 'Beter Bodembeheer - de diepte in' ( 6 april 2017) blijkt dat het gebruik van de meeste instrumenten gering is. Veel instrumenten zijn ofwel commercieel opgezet, of ontstaan als resultaat uit projecten. Deze laatste categorie maakt vaak dat wanneer het project afgerond is, het instrument niet meer onderhouden wordt. Er is geen centrale regie over de ontwikkeling van instrumenten.

De meeste instrumenten benaderen de bodemkwaliteit ofwel vanuit de chemische bodemvruchtbaarheid, naast een aanzienlijk aantal instrumenten met een integrale benadering (zowel chemisch, fysisch als biologisch). Enkele instrumenten richten zich specifiek op biologische of fysische aspecten. Het is opvallend dat veel van de geanalyseerde instrumenten gebruik maken van default data, en dus niet bedrijfs- of perceelsspecifieke data gebruiken, terwijl dit vanuit de gebruiker wel steeds meer gewenst is.

Naast dat het van belang is dat een instrument de bodemkwaliteit integraal benadert, is de integratie tussen de verschillende instrumenten ook van belang. Gebruikers zouden graag zien dat er meer interactie tussen de instrumenten plaatsvindt; bijvoorbeeld door koppeling aan de voorkant zodat niet steeds opnieuw dezelfde input gegevens ingevoerd hoeven worden, maar ook door koppeling aan de output kant, zodat adviezen elkaar niet tegenspreken. 


\section{$1 \quad$ Inleiding}

Bodembeheer is een actueel onderwerp in de landbouw: steeds meer akkerbouwers en ook melkveehouders zijn actief bezig met het verbeteren van hun bodembeheer. Allerlei organisaties en partijen spelen hierop in met het ontwikkelen en aanbieden van allerlei tools en instrumenten. Vanuit de PPS Duurzaam Bodembeheer was er behoefte aan overzicht in het aanbod aan instrumenten: wat is er beschikbaar, wat doen ze precies en van welke data maken ze gebruik? Maar ook: wie zijn de aanbieders, wie is de gebruiker en wat zijn de belangen van opdrachtgevers/aanbieders en gebruikers?

Deze studie is verricht in het kader van de PPS Beter Bodembeheer. Streefbeeld is dat binnen 10 jaar er per perceel een integraal bodemkwaliteitsplan ligt dat voor de fysische (structuur en water), chemische (bemesting), biologische (bodemgezondheid en bodemweerbaarheid) situatie de actuele stand van zaken beschrijft, de gewenste ontwikkeling neerzet, de maatregelen opsomt die genomen zullen worden en de wijze van evaluatie vastlegt. Bemestingsplannen, aaltjesbeheersingsplannen zijn voorbeelden van eerste losse elementen waar nu al mee gewerkt wordt en waarop kan worden voortgebouwd.

In deze verkenning wordt de actuele stand van zaken rond instrumenten voor duurzaam bodembeheer beschreven.

\section{$1.1 \quad$ Selectiecriteria}

In dit rapport worden 32 instrumenten voor duurzaam bodembeheer beschreven die aan de volgende criteria voldoen:

1. Er is sprake van een instrument, dat op basis van data komt tot een resultaat voor de gebruiker, in de vorm van inzicht of advies. Projecten en kennisoverdrachtsactiviteiten vallen hier niet onder, al maken ze soms gebruik van dergelijke instrumenten.

2. de instrumenten zijn momenteel beschikbaar (voorjaar 2017) of komen binnen afzienbare tijd beschikbaar (volgens planning binnen een jaar). Initiatieven met een langere tijdshorizon worden wel benoemd, maar niet verder uitgewerkt, omdat informatie ontbreekt of nog onvoldoende concreet is. Dat betekent ook dat het rapport een momentopname geeft.

3. De instrumenten zijn beschikbaar voor Nederlandse gebruikers in de akkerbouw en de melkveehouderij.

De instrumenten zijn verzameld door een combinatie van eigen kennis intern binnen de WUR, en vervolgens ook met behulp van kennis van ons externe netwerk. Gerard Ros (NMI) heeft een grote bijdrage geleverd aan het aanvullen van deze lijst. We hebben getracht een zo volledig mogelijke lijst samen te stellen. Echter kunnen we niet garanderen dat deze lijst $100 \%$ volledig is.

\subsection{Opbouw van het rapport}

In hoofdstuk 2 wordt het brede kader van duurzaam bodembeheer geschetst.

Voor de beschrijving in hoofdstuk 3 is gekozen om deze zo feitelijk/objectief mogelijk te houden, deels gebaseerd op openbare (online vindbare) informatie en waar nodig aangevuld met informatie van betrokkenen. Dit rapport typeert alle instrumenten kort aan de hand van vijf vragen: 'wat is het en wat doet het', 'wie is de eigenaar/leverancier', 'wie zijn de gebruikers', 'welke data worden gebruikt en wie heeft toegang tot input- en outputdata' en 'wat is de status van het instrument'. Dat betekent ook dat nadrukkelijk niet wordt ingegaan op de kwaliteit of gebruiksvriendelijkheid van de instrumenten of de (wetenschappelijke) onderbouwing ervan. Deze informatie is vaak ook niet beschikbaar, omdat 
instrumenten niet allemaal openbaar beschikbaar zijn voor een evaluatie én de achterliggende rekenregels niet worden getoond.

Er zijn verschillende soorten instrumenten, waarbij een deel gericht is op het monitoren/meten van de bodemkwaliteit of het bodembeheer, een tweede categorie bestaat uit management- en adviestools en een derde categorie op het verantwoorden van het bodembeheer aan derden. Deze driedeling is als uitgangspunt gekozen voor hoofdstuk 3 .

Vervolgens worden in hoofdstuk 4 alle tools onderling vergeleken op drie criteria:

a. Integraliteit: Is de tool gericht op zowel bodemstructuur, bodemvruchtbaarheid als bodemgezondheid, of slechts op één of twee van deze thema's?

b. Type bodemdata dat gebruikt wordt: worden perceelsspecifieke bodemdata gebruikt (die gemeten zijn door laboratoria of die zelf gemeten/bepaald zijn door de gebruiker van het instrument) of worden default data gebruikt (bijvoorbeeld referentiewaarden op basis van regio/grondsoort)?

c. Wat is het bereik van het instrument? Is het bruikbaar en beschikbaar voor een specifieke groep (sector, regio) of voor alle Nederlandse akkerbouwers en melkveehouders? NB hierbij gaat het om het effectieve bereik op dit moment (voorjaar 2017), niet om de potentie.

Tot slot worden enkele evaluerende opmerkingen gemaakt, deels op basis van een groepsdiscussie tijdens de bijeenkomst 'Beter Bodembeheer; de diepte in' op 6 april 2017 in Nijkerk. 


\section{Duurzaam bodembeheer: het kader}

Brundtland legde in 1987, als voorzitter van the World commission on environment and development van de Verenigde Naties in haar rapport "our common future", de basis onder het begrip duurzaamheid;

'Duurzame ontwikkeling is ontwikkeling die voorziet in de behoeften van de huidige generatie, zonder het vermogen aan te tasten van toekomstige generaties om in hun eigen behoeften te voorzien.' Report of the World Commission on environment and development: " our common future.", United Nations.

De bodem is letterlijk de basis onder ons bestaan. Om een groeiende wereldbevolking te voeden zullen de landbouwgronden blijvend zoveel mogelijk gezonde voeding moeten leveren bij een zo laag mogelijke input aan eindige grondstoffen. Naast voedselproductie speelt de bodem een cruciale rol als het gaat om het waterbeheer, biodiversiteit, het vastleggen van $\mathrm{CO}_{2}$ en de uitwisseling van klimaatgassen. Duurzaam bodembeheer om de kwaliteit van landbouwgronden te behouden en/of te verbeteren is daarom van essentieel belang.

Maar hoe meet je de kwaliteit van een bodem en wat is het effect van verschillende keuzes die in het bodembeheer gemaakt kunnen worden?

De bodem bestaat uit vier fracties. De minerale fractie, water, lucht en zowel dood als levend organisch materiaal (d.w.z. humus, plantenresten, bodemleven). Delen hiervan zoals de mineralen zijn een inherent gegeven, d.w.z. door het uitgangsmateriaal bepaald, en deze vertonen bijna geen veranderingen in de tijd. Andere delen zoals de organische fractie kunnen in loop van tijd veranderen. Deze vier fracties bepalen de randvoorwaarden waaronder de bodem diverse diensten/functies levert. Voor de landbouw staat de productiefunctie van de grond centraal. Dit is het vermogen om de productie van plantaardig biomassa te ondersteunen. Verder levert de bodem ook nog andere belangrijke maatschappelijke diensten zoals het filteren van, bufferen tegen, of onschadelijk maken van schadelijke stoffen m.b.t. tot lucht- en waterkwaliteit (filter- en klimaatfunctie), het reguleren van waterbewegingen en het vermogen als bewaarplaats voor planten en dieren te dienen (genetische bewaarplaats).

Deze diensten worden de ecosysteemdiensten van de bodem genoemd. Of en hoe "goed" de functies kunnen worden ingevuld is afhankelijk van verschillende processen die door de chemische, fysische en biologische bodemeigenschappen worden gestuurd. Dit zijn bv. m.b.t. de productiefunctie:

- $\quad$ het mobiliseren en vasthouden van nutriënten,

- de structuurvorming; dus het vormen van bodemaggregaten die zorgen voor een goede beschikbaarheid van water en lucht,

- het bufferen tegen ziektes en plagen.

De bodem is dus het fundament voor onze voedselproductie en daarmee naast water en lucht cruciaal voor ons overleven. De dagelijkse praktijk in de landbouw vormt echter een enorme belasting voor bodems. Maatregelen zoals de grondbewerking, de bemesting of het gebruik van pesticiden hebben allemaal invloed op de bodem en kunnen uiteindelijk leiden tot een daling van de bodemkwaliteit en vervolgens de voedselproductie. Zo stelt Oldeman $(1994)^{2}$ dat wereldwijd bijna $40 \%$ van alle landbouwgronden door menselijk handelen schade geleden heeft. Maar ook in Europa speelt bodemdegradatie een rol en zijn bijna 16\% van alle landbouwgronden onderhevig aan een of andere vorm van degradatie (EEA 2000) ${ }^{3}$.

Een opvallende ontwikkeling is de verandering in grondeigendom en grondgebruik. Het aantal ondernemers in de akkerbouw en de veehouderij blijft dalen terwijl het areaal gelijk blijft. Dit kan een indicatie voor ontkoppeling tussen eigendom en gebruik zijn, anderzijds kan het ook een indicatie voor schaalvergroting zijn. Daarnaast treedt steeds verdergaande specialisatie op. Dit uit zich bijvoorbeeld

\footnotetext{
2 Oldeman, L.R. (1994) The Global Extent of Soil Degradation. In: Greenland, D.J. and Szabolcs, I., Eds., Soil Resilience and Sustainable Landuse, CAB International, Wallingford, 99-119.

${ }^{3}$ EEA (2000). Are we moving in the right direction? Indicators on transport and environment integration in the EU. European Environment Agency, Copenhagen.
} 
in de bollenteelt en de pootgoedteelt waar de ondernemers een steeds groter areaal betelen terwijl ze het niet in eigendom hebben. Ze huren/pachten eenjarig, alleen voor de uitvoering van hun specifieke teelt. De grondeigenaar is vaak niet meer actief in de landbouw of heeft zelfs geen landbouwkundige achtergrond (bijvoorbeeld institutionele beleggers, overheden, waterleidingmaatschappijen of projectontwikkelaars). Het landbouwkundig beheer op langere termijn blijft daardoor onderbelicht en wordt verwaarloosd. Het is de uitdaging om juist in deze veranderde context van landgebruik eigenaren en pachters, instrumenten te bieden die het wederzijdse belang van jaarlijks goed bodembeheer laten zien en het hen mogelijk maken het beheer op elkaar af te stemmen zodat een ieder profiteert. Om deze instrumenten voor verantwoording van duurzaam bodembeheer een kans van slagen te geven is een evenwichtige balans tussen de belangen van eigenaren en grondgebruikers randvoorwaarde.

Terwijl het meten, veilig stellen en verbeteren van water- en luchtkwaliteit al lang op de agenda staat en we hiervoor zowel over meetbare indicatoren als ook bepaalde streefwaarden beschikken zijn we, met uitzondering van bodemverontreinigingen door zware metalen of pesticiden, pas recent gestart om meer aandacht aan de integrale kwaliteit van de bodem te schenken. Vier centrale vragen zijn hierbij:

1. Wat is bodemkwaliteit?

2. Welke bodemparameters zijn als indicatoren inzetbaar om de bodemkwaliteit te meten en zo antropogeen veroorzaakte veranderingen aantoonbaar te maken?

3. Waar liggen de streefwaarden voor mogelijke indicatoren? Dus waarden die gebruikt kunnen worden om een duurzaam bodemgebruik te sturen. Hoe kunnen zulke streefwaarden opgesteld worden?

4. Hoe kan de kennis over indicatoren \& streefwaarden zo naar de praktijk vertaald worden dat de bodemgebruikers (in ons geval akkerbouwers en veehouders) gestimuleerd worden om een duurzaam bodembeheer te implementeren ook al zijn ze zelf geen eigenaar van de grond. 


\section{Een overzicht van de instrumenten}

In dit hoofdstuk worden de gevonden instrumenten kort beschreven aan de hand van vijf vragen: 'wat is het en wat doet het', 'wie is de eigenaar/leverancier', 'wie zijn de gebruikers', 'welke data worden gebruikt en wie heeft toegang tot input- en outputdata' en 'wat is de status van het instrument' Onderstaand de lijst met instrumenten zoals deze nu (medio 2017) beschikbaar zijn:

Meten \& Monitoren:

- $\quad$ Bodembiologische indicatoren RIVM (BoBi)

- Bodemconditiescore

- Delphy bodemspiegel

- Monitoring Flevoland

- Verisscan

Management \& Advies:

- Aaltjesschema

- Akkerweb

- BodemQ (NMI)

- Bodemverkenner

- Delphy bemestingsplan

- Delphy bodemschat

- Demeter tool

- DLV mijNperceel.nl

- Handboek Bodem en Bemesting

- Hydrometra (6 Watermodules Kringloopwijzer)

- Mest en Mineraal (Agrifirm)

- MijNpercelen. nl, bemestingswijzer en TerraDecide (Eurofins)

- Mineralisatietool op KennisAkker

- NDICEA

- NemadecideGeo

- Nutrinorm bemestingsplanner

- Organische stof rekentool

- Slim Bemesten

- $\quad$ Sluiten mineralenkringlopen (NMI)

- Trijntje

- Wel en Wee app

Verantwoording:

- Bodempaspoort

- Boer \& Bunder

- Duurzaamheidsplan Veldleeuwerik

- Label duurzaam bodembeheer

- Milieukeur maatregelen

- Provincie NH: duurzaamheidscertificering voor pachtgronden

Hiernaast zijn er nog een aantal overige initiatieven die nog niet direct een instrument zijn, omdat ze nog in ontwikkeling zijn. De verwachting is dat deze initiatieven in de toekomst wel gaan leiden tot instrumenten. Deze worden apart benoemd in hoofdstuk 3.4. 


\subsection{Meten \& Monitoren}

\subsubsection{Bodembiologische Indicatoren (Bobi)}

Vraag 1 wat is het/ wat doet het? Korte beschrijving.

Bobi is een ondersteunend instrument bij ontwikkeling van het bodembeleid voor duurzaam gebruik van natuurlijke hulpbronnen. Het moet helpen bij het formuleren van milieubeleidsdoelstellingen. Over meerdere jaren worden veldbiologische gegevens verzameld over diversiteit van bodemorganismen en het verloop van processen bij verschillende bodems en landgebruik.

Vraag 2 belang achter het initiatief (wie)

De data worden verzameld door het RIVM in samenwerking met WUR, in opdracht van de toenmalige ministeries van VROM en LNV.

Vraag 3 beoogde gebruikers en hun belang

VROM en LNV willen met dit instrument een handvat hebben voor hun beleid aangaande bodemleven en bodemkwaliteit.

Vraag 4 data behoefte en toegang

Er worden metingen gedaan in verschillende bodemecosystemen op locaties gekoppeld aan het Landelijk Meetnet Bodemkwaliteit (LMB). Op de lange termijn zouden deze gegevens gekoppeld moeten zijn via 1 database.

Vraag 5 status

Financiering gestopt, laatste rapportage uit 2002.

http://www.rivm.nl/Documenten_en_publicaties/Wetenschappelijk/Rapporten/2002/mei/BoBI_op_weg _Tussentijdse_evaluatie_van_het_project_Bodembiologische_Indicator

\subsubsection{Bodemconditiescore}

Vraag 1 wat is het/wat doet het? Korte beschrijving.

Self assessment om de boer praktisch inzicht te geven in de kwaliteit van de bodem. Een low-tech methode gebaseerd op visuele indicatoren voor onder andere beluchting, waterhuishouding en organische stof. Met een formulier en handleiding die te downloaden zijn vanaf de website berekent de boer een score voor zijn bodem. Eventueel kunnen er ook tips verkregen worden naar aanleiding van de berekende score.

Vraag 2 belang achter het initiatief (wie)

De Bodemconditiescore is ontstaan als initiatief van CONO Kaasmakers, als instrument om de bodemkwaliteit bij melkveehouders de verbeteren en het bodembeheer de verduurzamen. De leerstoelgroep Soil Geography and Landscape van Wageningen Universiteit en Boerenverstand werken samen met het Louis Bolk Instituut, Wageningen Livestock Research en Aequator aan het instrument.

Vraag 3 beoogde gebruikers en hun belang

Boeren. Praktisch overzicht hoe de toestand van de bodem er voor staat, met name bodemfysisch.

Vraag 4 data behoefte en toegang

Zuurgraad en $\mathrm{pH}$ van bodemanalyse resultaten, plus eigen observaties uit het veld. In principe puur voor eigen gebruik. Bij verdere interesse kunnen resultaten overlegd worden met een van de initiatiefnemers, voor een individueel adviesrapport.

Het formulier en de handleiding is voor iedereen vrij beschikbaar online.

Vraag 5 status

Geïntroduceerd voor de praktijk in 2013. Nog steeds onderzoek en doorontwikkeling (PhD onderzoek WUR, door Soil Geography and Landscape). Handleiding specifiek voor Beemster gebied, meerdere handleidingen volgen in de toekomst. 


\subsubsection{Delphy bodemspiegel}

Vraag 1 wat is het/wat doet het? Korte beschrijving.

Bodemspiegel bestaat uit gewasbeelden, gemaakt met speciale camera's gemonteerd in bemande vliegtuigen. De gebruiker krijgt per perceel een serie beelden (3-5 afhankelijk van de wensen) gedurende het groeiseizoen:

- Gewone kleurenfoto van het gewas

- Biomassa, geeft inzicht in verschillen in gewasontwikkeling binnen een perceel, beeldresolutie $1 \mathrm{~m}^{2}$

- Stikstof-opname, geeft inzicht in verschillen in stikstofopname binnen een perceel, beeldresolutie, $1 \mathrm{~m}^{2}$

- Thermische kaart, laat verschillen zien in de gewastemperatuur binnen een perceel, in graden Celsius.

- $\quad$ CSV bestand dat kan worden gebruikt als basis voor het maken van zones en taakkaarten.

Vraag 2 belang achter het initiatief (wie)

De Digitale Bodemspiegel is ontwikkeld door Delphy, in samenwerking met Vigilance voor het invliegen van percelen en de verwerking van de data tot gewasbeelden.

Vraag 3 beoogde gebruikers en hun belang

Gebruikers zijn akkerbouwers, vollegrondsgroentetelers, bollentelers. De gewasbeelden geven informatie over verschillen binnen percelen, die vervolgens, in combinatie met aanvullende informatie, te gebruiken zijn voor plaats-specifieke managementmaatregelen zoals:

- $\quad \mathrm{N}$-bijmesting aardappel en tarwe.

- $\quad$ P en K-bemesting

- Biomassa afhankelijke dosering doodspuiten

- Organische stof en kalk

- Bodemherbicide of nematicide

- Identificeren zones voor grond- en gewasonderzoek

- Pootafstand aardappelen

- $\quad$ Diepere grondbewerking

Vraag 4 data behoefte en toegang

Sensingdata, de data is digitaal toegankelijk voor de gebruiker.

Vraag 5 status

Bodemspiegel is in de laatste 4 jaar ontwikkeld en is nu gereed voor praktisch gebruik. Nieuwe ontwikkelingen worden één keer per jaar verwerkt in een update.

\subsubsection{Monitoring Flevoland (door studenten van de Aeres Hogeschool)}

Vraag 1 wat is het/wat doet het? Korte beschrijving.

Vanuit diverse bodemkundige lesmodules krijgen studenten opdracht om te oefenen met de geleerde technieken voor de beoordeling van de bodemkwaliteit. Zij doen dit op bedrijven/percelen van bestaande praktijknetwerken, waarmee ze vervolgens ook de discussie voeren over de interpretatie van de resultaten. Als dit elk jaar structureel wordt uitgevoerd ontstaat een database die wellicht geschikt is om langjarige tendensen te herkennen al dan niet in combinatie met andere (publieke) datasets (big data analyse).

Bodemkwaliteit wordt breed gedefinieerd: fysisch, chemisch en biologisch.

Vraag 2 belang achter het initiatief (wie)

Aeres Hogeschool Dronten, m.n. het lectoraat Duurzaam Bodembeheer, samen met de provincie Flevoland als financier. 
Vraag 3 beoogde gebruikers en hun belang

De ondernemers van betrokken praktijknetwerken zijn de primaire doelgroep van de

analyseresultaten. De studenten van de Aeres Hogeschool krijgen meer inzicht in bodemkwaliteit en bodembeheer in de praktijk door het doen van bodemanalyses en deze te vertalen in een advies aan de grondeigenaar/gebruiker. Als de opbouw van een doorlopende datareeks van de grond komt, kunnen geanonimiseerde analyseresultaten en conclusies inzicht geven aan beleidsmakers en bestuurders (overheid, waterschap en sector) in de status en ontwikkeling van de bodemkwaliteit. Of dit ook kan leiden tot concrete actie (beleidsinterventies, projecten) is niet duidelijk.

Vraag 4 data behoefte en toegang

Vanuit het lectoraat wordt een plan gemaakt voor de bodemanalyses, om bruikbare langjarige reeksen te krijgen. Het is op dit moment nog niet definitief vastgesteld welke indicatoren en methodes gebruikt zullen worden.

Vraag 5 status

In opstart (opdracht is eind 2016 verstrekt). Momenteel (voorjaar 2017) wordt een pilot uitgevoerd door enkele studenten.

\subsubsection{Verisscan}

Vraag 1 wat is het/wat doet het? Korte beschrijving

De Verisscan is een apparaat dat wordt gekoppeld aan een trekker. Het scant via een woelpoot en schijven met o.a. NIRS om de 10 meter de bodem. Het bepaalt de $\mathrm{pH}$, OS en elektrische geleidbaarheid (EC). De Veris bodemadviesdienst van Agrifirm biedt op basis van de scan een hele serie basiskaarten (Hoogte, EC30, EC90, pH, OS, Lutum etc). Vanuit de scan kan een zogenaamde taakkaart gemaakt worden die aangeeft waar de gehaltes hoog of laag zijn. Op basis van deze gegevens kan bijvoorbeeld specifiek bemest of bekalkt worden, afhankelijk van de gemeten waarden.

Vraag 2 belang achter het initiatief (wie)

Veris technologies (http://www.veristech.com) is een Amerikaans bedrijf dat de technologie ontwikkelt. In Europa worden zij vertegenwoordigd door Agrometius. Agrifirm ontwikkelt i.s.m. Agrometius steeds meer nieuwe toepassingen op basis van de scan gegevens (https://www.agrifirm.nl/aanbod/veris-bodemadvies/).

Vraag 3 beoogde gebruikers en hun belang

Veehouders en akkerbouwers

Vraag 4 data behoefte en toegang

De Veris scan maakt geen gebruik van achtergrondgegevens maar baseert zich op de data van de scan gecombineerd met de uitkomst van een aantal ijkmonsters die ten tijde van de scan zijn genomen. De gemeten perceelsdata zijn eigendom van de perceelseigenaar. Data verzameling en beheer vallen onder de gedragscode datagebruik akkerbouw (http://www.bo-akkerbouw.nl/wpcontent/uploads/2016/12/GEDRAGSCODE-datagebruik-akkerbouw-v161221.pdf)

Vraag 5 status

Beschikbaar

http://www. agrometius. nl/producten/veris-msp3-bodemscanner

\subsection{Management \& Advies}

\subsubsection{Aaltjesschema}

Vraag 1 wat is het/wat doet het? Korte beschrijving. www.aaltjesschema. $\mathrm{nl}$ is een website die kennis over waardplantstatus en schadegevoeligheid van gewassen voor de meeste plantparasitaire aaltjessoorten ontsluit. 
Het eerste initiatief dateert uit 1967 waarbij met stippen de waardplantstatus en kleuren de schadegevoeligheid schematisch werd weergegeven. PAGV gebruikt sinds 15 jaar dezelfde systematiek om nieuwe informatie toe te voegen. Op de site kan de teler gewassen en groenbemesters combineren met de gewenste aaltjessoorten in een maatwerk aaltjesschema. Door dubbel te klikken op een combinatie wordt achtergrondkennis ontsloten.

Vraag 2 belang achter het initiatief (wie)

De onderzoeksgroep nematologie van P-AGV legt wetenschappelijk valide informatie uit projecten vast in aaltjesschema, waardoor in de loop van de tijd een waardevolle database opgebouwd die online toegankelijk is.

Vraag 3 beoogde gebruikers en hun belang

Telers en adviseurs. Hun belang is betrouwbare informatie te kunnen vinden waarmee ze hun bouwplannen kunnen opzetten.

Vraag 4 data behoefte en toegang

Teler voert zelf de data in van gewassen en aaltjes waar hij informatie over wil. De site is gratis en voor een ieder toegankelijk.

Vraag 5 status

PAGV beheert de site actief en actualiseert in mei/jun en november/december van elk jaar.

www.aaltjesschema.nl

\subsubsection{Akkerweb}

Vraag 1 wat is het/wat doet het? Korte beschrijving.

Akkerweb is een centraal geo-platform dat alle perceels informatie bij elkaar brengt. Dit omvat bouwplaninformatie vanuit RVO, bodemkaarten, biomassakaarten vanuit satellieten en de informatie die de teler zelf aan zijn percelen toevoegt, zoals bijvoorbeeld zijn aaltjesuitslagen. De informatie kan de teler delen met zijn contacten Dit platform is in februari 2016 gelanceerd. Via app's en adviesmodules die aan Akkerweb zijn gekoppeld, worden de opgeslagen data omgezet in informatie die de teler actief kan benutten voor zijn bedrijfsvoering. Aan Akkerweb gelieerde applicaties die van belang zijn voor bodembeheer zijn o.a. NemaDecideGeo, Agrifirm mineraal, Bioscope, Wel en Wee app (beschikbaar najaar 2017).

Vraag 2 belang achter het initiatief (wie)

Akkerweb is voortgekomen uit het initiatief NemaDecide (www.nemadecide.nl). Daarin werken Agrifirm Plant, Vinçotte ISACert (voorheen NAK-AGRO), aardappelhandelshuizen en WUR (Agrosysteemkunde, PAGV) samen aan een aaltjes adviestool voor de beheersing van aaltjes in de aardappelteelt. T.b.v. van de aanvraag van aaltjesmonsters en het beschikbaar maken en houden van aaltjesuitslagen werd een webservice ontwikkeld voor de uitwisseling van aaltjesuitslagen en een geografisch informatie systeem waarin deze gegevens worden bewaard en kunnen worden gekoppeld aan de DSS NemaDecide. Toen bleek dat dit voor aaltjes zeer goed functioneerde ontstond de behoefte niet alleen aaltjesgegevens maar alle gegevens die beschikbaar zijn van een perceel op $x, y$ coördinaat te ontsluiten. Akkerweb is het resultaat.

Vraag 3 beoogde gebruikers en hun belang

Boeren en hun adviseurs: beter advies per perceel, meer informatie over percelen, alle info in één overzicht. De meeste applicaties richten zich nu nog op de akkerbouw maar er komen steeds meer initiatieven gekoppeld aan de veehouderij (bv adviesmodule Grip op Gras).

Ook behoren ontwikkelaars van apps en adviesmodules tot de doelgroep.

Vraag 4 data behoefte en toegang

Aanbieders van geo-data, zoals RVO, laboratoria en telers zelf kunnen deze data via akkerweb ontsluiten. Het data-aanbod groeit nog steeds. Het principe van akkerweb is dat alle perceelsdata van 
de eigenaar zijn. De eigenaar kan zelf partijen toegang geven tot data van zijn perceel, zoals zijn adviseur, afnemer of huurder.

Vraag 5 status

Akkerweb is in februari 2016 geïntroduceerd in de praktijk, maar tegelijk nog volop in ontwikkeling (meer data, meer applicaties, meer aanbieders, meer gebruikers).

www.akkerweb.nl

\subsubsection{BodemQ (NMI)}

Vraag 1 wat is het/wat doet het? Korte beschrijving.

BodemQ is een beoordelingsinstrument van het NMI. Met BodemQ is bij uitstek de bodemkwaliteit op basis van de nieuwste kennis en inzichten te beoordelen. De invalshoek kan hierbij landbouw, natuur of bodemecosysteemdiensten (klimaat, water, biodiversiteit) zijn. Het geeft een gewogen en integrale beoordeling van de bodemkwaliteit, rekent met chemische, biologisch en fysische bodemeigenschappen, benoemt geschiktheid en verbeterpunten en geeft concrete handvatten voor bewust bodembeheer. BodemQ gebruikt basisdata van regulier grondonderzoek, bodemkartering, veldonderzoek en gebruikerskennis. Dit kan worden aangevuld met specifieke informatie uit sensormetingen, bodembiodiversiteit, etc. BodemQ berekent uit deze metingen de bodemfuncties (bijvoorbeeld $\mathrm{N}$-levering, bodemgezondheid, slempgevoeligheid) en zet die om in een integrale, gewogen waardering van de bodemkwaliteit.

Vraag 2 belang achter het initiatief (wie)

BodemQ is ontwikkeld door het NMI om de bodemkwaliteit te relateren aan een doelfunctie.

Vraag 3 beoogde gebruikers en hun belang

Terreinbeheerders, provincies, waterschappen: gebiedsspecifiek inzicht in bodemproblemen en mogelijke oplossingen.

Agrarische ondernemers: kwantificeren bodemkwaliteit in kader van pachtcontracten, en verbetering bodembeheer (onderdeel van bodembeheerplan) voor agrarische productie/ waterbeheer/ natuurontwikkeling etc.

Vraag 4 data behoefte en toegang

Gebruikt beschikbare routinematige analyses van Eurofins Agro als uitgangspunt.

Wordt uitgebreid met generiek beschikbare (open source) databases rond bodem, landgebruik, hydrologie en weer.

Vraag 5 status

Beschikbaar als onderzoekstool. Web-applicatie in ontwikkeling door het NMI.

https: //www.nmi-agro.nl/tools/bodem-q

\subsubsection{Bodemverkenner}

Vraag 1 wat is het/ wat doet het? Korte beschrijving.

Een add-on ontwikkelt voor de KringloopWijzer waarmee een agrarische ondernemer op een snelle manier inzicht krijgt in de belangrijkste mineralenstromen op zijn bedrijf, en de mogelijkheid heeft om het effect van maatregelen op o.a. 1) mineralenbalansen, 2) ruwvoerproductie, 3) bedrijfsfinanciën, 4) milieu, en 5) bodemkwaliteit inzichtelijk te maken. Elk bedrijf krijgt snel een overzicht van kansen/ problemen, en een top-5 aan maatregelen die inspelen op verbetering bodemgebruik, mineralenefficiëntie, en financiële meerwaarde.

Vraag 2 belang achter het initiatief (wat, wie) Is door NMI en ETC ontwikkeld binnen het project Duurzaam Boer Blijven Drenthe, voortbouwend op een voorloper van de KringloopWijzer (KLW) ontwikkeld voor LNV in de jaren ‘ 90.

Vraag 3 beoogde gebruikers en hun belang 
Melkveehouders en hun adviseurs. Het geeft een praktisch overzicht van de goede en verbeterpunten op het bedrijf.

Vraag 4 data behoefte en toegang

Applicatie is ontwikkeld als toevoeging op de KLW. Informatie vanuit de KLW is vereiste input. Daarnaast draait het op default invoergegevens en kan de gebruiker het meer en meer bedrijfsspecifiek maken door eigen gegevens in te voeren.

Vraag 5 status

Als applicatie beschikbaar bij het NMI. In samenwerking met ZuivelNL wordt gewerkt aan koppeling met de KLW. Komt naar verwachting in 2018 beschikbaar voor de sector.

https://www.nmi-agro.nl/tools/bodemverkenner

\subsubsection{Delphy bemestingsplan}

Vraag 1 wat is het/wat doet het? Korte beschrijving.

Het bemestingsplan geeft perceel-specifiek adviezen voor bodem en bemesting:

- Bemestingsadviezen, op basis van grondonderzoek

- Mineralen balans per jaar en per rotatie, op basis van werkelijke opbrengsten

- Organische stofbalans op basis van werkelijke inputs uit gewasresten, stro, groenbemesters, plantaardige en dierlijke organische mest.

- Kosten van bemesting op basis van actuele prijzen

Vraag 2 belang achter het initiatief (wie)

Gemaakt in opdracht van Delphy om beter advies aan klanten te kunnen geven.

Vraag 3 beoogde gebruikers en hun belang

Gebruikers zijn adviseurs van Delphy, voor advisering van akkerbouwers. Het programma geeft maatwerk op perceelsniveau, optimale bemestingsadviezen tegen minimale kosten, passend binnen wet- en regelgeving.

Vraag 4 data behoefte en toegang

Perceel-specifieke bodem- en bemestingsgegevens. Omdat het een pc-applicatie betreft, is deze data niet toegankelijk voor anderen.

Vraag 5 status

Programma krijgt ieder jaar een update.

\subsubsection{Delphy Bodemschat}

Vraag 1 wat is het/wat doet het? Korte beschrijving.

Bodemschat bepaalt de potentiële productie van een perceel aan de hand van de fysische bodemaspecten en geeft adviezen voor verbeteringen, bijvoorbeeld over grondbewerking, organische stofbeheer, egalisatie, drainage, diepe grondbewerking. De adviezen zijn overzichtelijk weergegeven in tabellen en grafieken. Bodemschat is een instrument voor bewust en duurzaam bodembeheer.

Vraag 2 belang achter het initiatief (wie)

Bodemschat is ontwikkeld door Delphy.

Vraag 3 beoogde gebruikers en hun belang

Bodemschat is van toepassing op alle telers van gewassen in de vollegrond. Optimale bodemkwaliteit is van groot financieel belang voor iedere ondernemer. Bodemschat geeft inzicht in de fysische conditie van de bodem, knelpunten, haalbare verbeterpunten en financiële voordelen van het aanpakken van de knelpunten. 
Vraag 4 data behoefte en toegang

Het programma werkt op basis van perceel-specifieke fysische bodemkenmerken. Het betreft een stand-alone toepassing.

Vraag 5 status

Het programma is beschikbaar en wordt jaarlijks onderhouden.

\subsubsection{Demeter tool}

Vraag 1 wat is het/wat doet het? Korte beschrijving.

De Demetertool geeft inzicht in de koolstofevolutie, de fosforbalans en de stikstofbalans voor een bepaald perceel. Met bedrijfsspecifieke gegevens worden deze balansen over de tijd berekend, en wordt er een advies gegeven.

Vraag 2 belang achter het initiatief (wat, wie)

De tool is gemaakt door de Vlaamse Landmaatschappij, onder andere in samenwerking met het NMI.

Vraag 3 beoogde gebruikers en hun belang

De tool is ontwikkeld voor telers/adviseurs in Vlaanderen en Nederland. Zij kunnen met deze tool meer inzicht krijgen in de nutriëntenbalansen op hun bedrijf op perceelsniveau.

Vraag 4 data behoefte en toegang

De tool vraagt veel data. Er zijn onder andere gegevens nodig over het bedrijf, het perceel, de rotatie en de bemesting. De tool is voor iedereen beschikbaar via de website.

Vraag 5 status

Beschikbaar voor de praktijk.

Eloket.vlm.be/demeter en https://www.nmi-agro.nl/tools/demeter-tool-duurzaam-bodembeheer

\subsubsection{DLV mij Nperceel.nl}

Vraag 1 wat is het/wat doet het? Korte beschrijving.

DLV Advies heeft een gratis online bemestingstool voor klanten gemaakt voor grasland om per perceel en per verwachte snede de mestgift te kunnen berekenen.

Vraag 2 belang achter het initiatief ( wie)

DLV Advies / Delphy geeft klanten hiermee eenvoudiger en sneller advies over de bemesting van grasland.

Vraag 3 beoogde gebruikers en hun belang

Het belang van de gebruiker is dat de mestgift beter wordt afgestemd op de verschillen tussen percelen (bodem, verwachtte grasopbrengst). Dat levert financieel voordeel op (meer opbrengst per $\mathrm{kg} \mathrm{N})$.

Vraag 4 data behoefte en toegang

MijNperceel integreert voor DLV-klanten de gegevens van de Mestwetplanner en Optimest, waardoor alle gegevens van de klant beschikbaar zijn. Via een login kan alleen de gebruiker bij deze gegevens.

Vraag 5 status

Beschikbaar.

http://www.dlvadvies.nl/mest/managementtools/dlv-mijnperceel en www.dlvmijnperceel.nl

\subsubsection{Handboek Bodem en Bemesting}

Vraag 1 wat is het/wat doet het? Korte beschrijving. 
Een online handboek met concrete adviezen en handvatten over bodembeheer voor telers en adviseurs. Het handboek bevat de bemestingsadviezen, adviezen over grondbewerkingen, groenbemesters, bodemkwaliteit etc.

Vraag 2 belang achter het initiatief (wie)

Het handboek is opgesteld door de CBAV (Commissie Bemesting Akkerbouw en Vollegrondsgroente), met financiering vanuit het Masterplan Mineralen Management. Het handboek heeft een landbouwkundige grondslag, wat wil zeggen dat het bemestingsadvies leidt tot een economisch optimaal resultaat.

Vraag 3 beoogde gebruikers en hun belang

Telers, adviseurs, en alle andere personen betrokken bij het beheer van de bodem in de akkerbouw en vollegrondsgroenteteelt kunnen dit handboek gebruiken. Het geeft adviezen, handvatten en achtergrondinformatie die kan worden toegepast voor een optimale bemesting en optimaal bodembeheer.

Vraag 4 data behoefte en toegang

Gebruik van de informatie behoeft geen input data, wel wordt er geadviseerd om met eigen kennis en kunde de adviezen te vertalen naar de eigen praktijk situatie. Het handboek is beschikbaar voor iedereen op internet.

Vraag 5 status

Functionerend, en wordt steeds geactualiseerd.

http://www.handboekbodemenbemesting.nl

\subsubsection{Hydrometra (6 watermodules in KringloopWijzer)}

Vraag 1 wat is het/ wat doet het? Korte beschrijving.

WUR ontwikkelt diverse watermodules die onderdeel gaan worden van de KringloopWijzer. Het zijn de modules: erf (activiteitenbesluiten, vermijden NP-verliezen), droogte (zorgen voor betere opbrengst en bodemkwaliteit), wateroverlast (vermijden natschade, verbetering infiltratie en berging), grondwater (vermindering uitspoeling), oppervlaktewater (verbetering waterkwaliteit), drinkwater vee en slootbeheer (behoud afvoercapaciteit en verbeteren ecologische kwaliteit). De modules moeten de ondernemer inzicht geven in het effect van zijn huidig bedrijfsstructuur en management, en oplossingen bieden voor verbetering.

Vraag 2 belang achter het initiatief (wat, wie)

De modules worden ontwikkeld door WUR.

Vraag 3 beoogde gebruikers en hun belang

Melkveehouders en adviseurs kunnen inzicht krijgen in de mineralenstromen op het bedrijf.

Vraag 4 data behoefte en toegang

Gegevens blijven eigendom van ondernemer, en worden opgeslagen in centrale database van KringloopWijzer. Betrokken adviserende bedrijven/ organisaties kunnen toegang krijgen tot deze gegevens als de ondernemer daarmee instemt.

Vraag 5 status

In ontwikkeling door Wageningen UR (en andere partijen), o.a. op Koeien \& Kansen bedrijven. Niet op korte termijn operationeel voor de praktijk.

http:// www. wur.nl/nl/project/HYDROMETRA-het-instrument-voor-de-onderbouwing-van-agrarischebedrijfswaterplannen.htm 


\subsubsection{Mest en Mineraal (Agrifirm via Akkerweb)}

Vraag 1 wat is het/ wat doet het? Korte beschrijving.

Dit is een bemestings adviesmodule die ontwikkeld is op basis van openbare kennis (adviesbasis) in combinatie met die van Agrifirm bemestingsspecialisten. Via akkerweb wordt specifieke perceelsinformatie gebruikt in combinatie met de adviesnormen om voor elk perceel tot het juiste strooiadvies te komen. De adviseur stelt in overleg met de klant op deze wijze voor het hele bedrijf een bemestingsplan op, inclusief een organische stofbalans.

Vraag 2 belang achter het initiatief (wie)

Agrifirm heeft met deze tool de mogelijkheid om op efficiënte wijze tot bemestingsadviezen te komen. Dit geïntegreerd met hun interne logistieke systemen maakt het tot een krachtige tool.

Vraag 3 beoogde gebruikers en hun belang

Akkerbouwers, groentetelers, bollentelers en fruittelers.

Vraag 4 data behoefte en toegang

Bouwplan akkerweb en de bodemanalyses per perceel. Alleen Agrifirm adviseurs hebben toegang tot de data en kunnen het advies met de klant delen

Vraag 5 status

Beschikbaar op akkerweb

\subsubsection{Mijn percelen.nl, bemestingswijzer en TerraDecide (Eurofins)}

Vraag 1 wat is het/wat doet het? Korte beschrijving.

Met Mijn Percelen biedt Eurofins Agro klanten online inzicht in de bodemanalyses en de daarop gebaseerde adviezen per perceel. Daarnaast biedt Eurofins klanten verschillende adviesapplicaties, zoals de bemestingswijzer (bouwland en grasland) en Terradecide. Beide tools adviseren op basis van bodemanalyses, gewas/bouwplaninformatie en bemestingsnormen.

Vraag 2 belang achter het initiatief (wie)

Eurofins Agro

Vraag 3 beoogde gebruikers en hun belang Klanten van Eurofins hebben eenvoudig en overzichtelijk inzicht in de bemonsteringsuitslagen per perceel en kunnen via apps ook specifiek advies krijgen per perceel.

Vraag 4 data behoefte en toegang

Bemonsteringsuitslagen van Eurofins in opdracht van de telers, bedrijfs- en perceelsgegevens. Telers hebben zelf toegang via een login.

Vraag 5 status

Beschikbaar.

http://mijnpercelen. blgg.agroxpertus. nl/ en http://eurofins-agro.com/nl-

$\mathrm{nl}$ /product/ bemesting/bemestingswijzer-bouwland en http://eurofins-agro.com/nl- $\mathrm{nl} /$ wat-terradecide

\subsubsection{Mineralisatietool KennisAkker}

Vraag 1 wat is het/wat doet het? Korte beschrijving.

In opdracht van het Masterplan Mineralen Management (MMM) is een eenvoudige rekentool (in Excel) ontwikkeld, waarmee akkerbouwers een betere inschatting kunnen maken van de bodemmineralisatie en daarmee van de benodigde aanvullende bemesting. De tools is een vereenvoudiging van NDICEA (zie paragraaf 3.2.14). 
Vraag 2 belang achter het initiatief (wie)

Gemaakt in opdracht van het Masterplan Mineralen Management (2011-2013): dit was een

programma van LTO, de Nederlandse Akkerbouw Vakbond en het Productschap Akkerbouw, gericht op het bevorderen van een efficiënte inzet van mineralen en het behalen van de milieudoelen (o.a.

waterkwaliteit). Binnen MMM werd kennis en instrumentarium ontwikkeld voor de sector, waaronder deze rekenmodule.

Vraag 3 beoogde gebruikers en hun belang

Door de (stikstof) bemesting beter af te stemmen op de bodemmineralisatie en de gewasbehoefte, kan de akkerbouwer de stikstofbemesting effectiever inzetten: niet te weinig, maar ook niet teveel. Deze rekenmodule is eenvoudiger dan NDICEA, en daarom gebruiksvriendelijker.

Vraag 4 data behoefte en toegang

Perceelsspecifieke bodem- en bemestingsgegevens, in te voeren door de gebruiker. Omdat het een offline applicatie betreft, is deze data niet toegankelijk voor anderen.

Vraag 5 status

Beschikbaar als download. Sinds 2013 niet meer geactualiseerd.

http://www.kennisakker.nl/node/4016

\subsubsection{NDICEA}

Vraag 1 wat is het/ wat doet het? Korte beschrijving

Mineralisatiemodel wat de stikstof- en organische stof dynamiek (incl. uitspoeling) voorspelt van bouwplannen op verschillende grondsoorten. De gebruiker kan verschillende scenario's met elkaar vergelijken.

Vraag 2 belang achter het initiatief (wie)

Ontwikkeld door Louis Bolk Instituut in opdracht van het toenmalige ministerie van LNV en Hoofdproductschap Akkerbouw binnen het project ' Grond onder Bemesting'. Later is het geactualiseerd binnen het EU onderzoeksproject N-Toolbox. Het model is nogmaals vernieuwd en gebruikt binnen het EU project Tilman-org.

Vraag 3 beoogde gebruikers en hun belang

Adviseurs en boeren die hiermee inzicht krijgen in de meerjarige stikstof- en organische stofdynamiek en kunnen spelen met scenario's waarin o.a. de vruchtwisseling en de bemesting worden aangepast. De tool laat grafisch zien of de gewasbehoefte / opname matcht met het aanbod van stikstof, maar ook hoe de organische stof zich over de jaren heen ontwikkelt.

Vraag 4 data behoefte en toegang

Rotatie (gewassen+volgorde) en bemesting (reëel of fictief). Offline tool (download), dus anderen hebben geen toegang tot ingevulde data.

Vraag 5 status

Beschikbaar

www.ndicea.nl

\subsubsection{NemaDecideGeo}

Vraag 1 wat is het/wat doet het? Korte beschrijving.

NemaDecideGeo is een adviestool voor de beheersing van aaltjes. In eerste instantie voor aardappelmoeheid in aardappelen maar nu ook voor andere aaltjessoorten in de hele rotatie. De tool adviseert telers bij rassenkeus, vruchtwisseling, grondontsmetting, niet chemische bestrijding en 
grondbemonstering. In NemaDecideGeo is via Akkerweb de koppeling gemaakt met geospecifieke data van een perceel, o.a. de teelt- en bemonsteringshistorie en besmettingsniveaus binnen een perceel.

Vraag 2 belang achter het initiatief (wie)

NemaDecideGeo is voortgekomen uit het initiatief NemaDecide (www.nemadecide. nl). Daarin werken Agrifirm Plant, Vinçotte ISACert (voorheen NAK-AGRO), aardappelhandelshuizen en WUR (Agrosysteemkunde, PAGV) om de bestaande aaltjeskennis van WUR te combineren met bemonsteringsinformatie, rasinformatie en bestrijdingsmaatregelen.

Vraag 3 beoogde gebruikers en hun belang

Akkerbouwers en hun adviseurs: beter advies per perceel, meer informatie over percelen, alle info in één overzicht.

Vraag 4 data behoefte en toegang

NemaDecideGeo gebruikt de informatie die via de bouwplanmodule, de bemonsteringsmodule en de aardappelrasmodule van Akkerweb wordt opgehaald. De eigenaar kan zelf partijen toegang geven tot aaltjesdata van zijn perceel, zoals zijn adviseur, afnemer of huurder.

Vraag 5 status

NemaDecideGeo is sinds maart 2017 als webapplicatie beschikbaar en zal in het najaar van 2017 actief worden gepromoot.

\subsubsection{Nutrinorm bemestingsplanner}

Vraag 1 wat is het/ wat doet het? Korte beschrijving.

De Nutrinorm bemestingsplanner maakt een bemestingsadvies op basis van bodemanalyses en wettelijke gebruiksruimte. De tool is ontwikkeld op basis van onderzoek van Wageningen University \& Research door OCl Agro en Eurofins Agro en is gratis beschikbaar.

Vraag 2 belang achter het initiatief (wie)

$\mathrm{OCl}$ Agro en Eurofins Agro zijn de belangrijkste initiatiefnemers. Via de bemestingsplanner bieden ze een goed onderbouwd bemestingsadvies aan gebruikers, wat gebruik maakt van beschikbare bodemanalyses (Eurofins) en beschikbare meststoffen $(\mathrm{OCl})$.

Vraag 3 beoogde gebruikers en hun belang

Akkerbouwers, veehouders en hun adviseurs kunnen eenvoudig hun bemestingsplan opstellen via deze tool, waarbij voorzien wordt in de gewasbehoefte en rekening houdend met de bodemvruchtbaarheid, binnen de wettelijke gebruiksruimte. Goed verdelen van de beschikbare gebruiksruimte over de gewassen en percelen is financieel voordelig.

Vraag 4 data behoefte en toegang

De tool maakt gebruik van beschikbare bodemanalyses en perceels- en bedrijfsinformatie (bouwplan, teelt- en bemestingshistorie). Via een login kan alleen de gebruiker bij deze gegevens.

Vraag 5 status

Beschikbaar.

www. nutrinorm.nl

\subsubsection{Organische stof rekentool}

Vraag 1 wat is het/ wat doet het? Korte beschrijving.

De organische stof rekentool ondersteunt in het maken van de organische stofbalans op perceels- en bedrijfsniveau. De tool geeft inzicht in de organische stofstromen, zodat de gebruiker kan inzien of het nodig is het management qua organische stofbeheer aan te passen. Dit gebeurt door invoer van bedrijfsspecifieke gegevens, waarmee per perceel een balans kan worden uitgerekend. 
Vraag 2 belang achter het initiatief (wie)

De tool is een initiatief van Stichting Milieukeur en is opgezet door NMI.

Vraag 3 beoogde gebruikers en hun belang

De organische stof rekentool is gemaakt voor Milieukeurtelers, om inzicht te krijgen in de organische stof balans op het bedrijf, en eventueel veranderingen aan te brengen in de toevoer van organische stof.

Vraag 4 data behoefte en toegang

De tool vraagt veel bedrijfsspecifieke data over de bodem, het gewas en de bemesting. Voor mest- en gewasgehaltes wordt geput uit een database, maar ook hier is de mogelijkheid om gegevens aan te passen naar de bedrijfsspecifieke situatie.

Vraag 5 status

Beschikbaar via de website van NMI, wordt onderhouden.

https://www.nmi-agro.nl/tools/organische-stof-rekentool

\subsubsection{Slim Bemesten}

Vraag 1 wat is het/wat doet het? Korte beschrijving

Specifiek voor de waterwingebieden in Zuid-Limburg (lössgronden) is een tool ontwikkeld die boeren van een bemestingsadvies voorziet met minimale risico's voor de drinkwaterkwaliteit. In de achterliggende rekenregels is een aanpassing gemaakt voor de specifieke eigenschappen van het lössgebied, omdat m.n. de Waterleiding Maatschappij Limburg (WML) vond dat de bestaande modellen dat onvoldoende deden.

Vraag 2 belang achter het initiatief (wie)

De WML is hoofdbelanghebbende, als verantwoordelijke voor de waterkwaliteit in de waterwingebieden.

Vraag 3 beoogde gebruikers en hun belang

Boeren in drinkwaterwingebieden in Zuid-Limburg, met hun adviseurs. Zij kunnen door het gebruik van deze tool toch gebruik blijven maken van de gronden in de waterwingebieden voor agrarische productie.

Vraag 4 data behoefte en toegang

Tool werkt op basis van bedrijfsgegevens (gewassen, rotatie etc) en bodemdata.

Vraag 5 status

Beschikbaar.

https: //www. Iltb.nl/nieuwsberichten/website/2015/05/pilot-slim-bemesten

\subsubsection{Sluiten mineralenkringlopen (NMI)}

Vraag 1 wat is het/ wat doet het? Korte beschrijving.

Toolkit / rekenmodule waarmee akkerbouwers kunnen bepalen hoe uiteenlopende organische mesten reststoffen uit de regio ingepast kunnen worden in het bemestingsplan van akkerbouwbedrijven in Noordoost Nederland t.b.v. de ontwikkeling van een klimaatbestendige bodem. Deze toolkit bestaat uit 3 onderdelen:

1) karakterisering van de uiteenlopende organische mest- en reststoffen tav de volgende aspecten: organische stoflevering (gehalte en stabiliteit organische stof in product, bekalkende waarde, gehalte en beschikbaarheid nutriënten, CO2-voetafdruk, en prijs voor aanschaf, transport, opslag (eventueel) en toediening.

2) Kwantificering van behoefte aan organische stof, bekalking / pH-verhoging en nutriënten op percelen van akkerbouwbedrijven. 
3) Op basis van 1 en 2 wordt de inzetbaarheid van de producten uit 1 in het bemestingsplan van akkerbouwbedrijven bepaald, ten opzichte van enkele referentiemeststoffen.

Vraag 2 belang achter het initiatief (wie)

De tool is ontwikkeld door het NMI.

Vraag 3 beoogde gebruikers en hun belang

Akkerbouwers: beter inspelen met mest- en bodembeheerplan op basis van regionaal beschikbare organische reststromen, met keuzeflexibiliteit voor ondernemer. Kringloopsluiting op bedrijfsniveau. Producenten van organische reststoffen: beoordeling van inpasbaarheid meststof binnen gangbare bouwplannen, en mogelijk informatieverspreiding over de landbouwkudnige waarde van de beschikbare producten.

Vraag 4 data behoefte en toegang

Programma maakt gebruik van generiek beschikbare gegevens qua bouwplan, bemesting en meststofgegevens. Agrarische ondernemers kunnen modelresultaten afstemmen op hun eigen bedrijfssituatie en een gericht advies krijgen voor de best passende organische meststof op hun bedrijf (best passend volgens eigen in te vullen criteria).

Vraag 5 status

Beschikbaar als onderzoekstool/ ingezet bij gebruikers in praktijknetwerk in Drenthe.

Agrifirm had interesse, maar had geen budget om tool online beschikbaar te maken.

$\mathrm{NMI}$ is bezig om een consortium op te zetten waarmee een Organische Meststoffen Database online beschikbaar kan worden gemaakt, vergelijkbaar met de Minerale Meststoffen Database van MMF.

\subsubsection{Trijntje}

Vraag 1 wat is het/ wat doet het? Korte beschrijving.

Trijntje is platform met apps (in ontwikkeling) wat akkerbouwers wil helpen om hun bodembeheer te verbeteren en daarin waterbeheersdoelen te integreren. Het is bekend dat bodembeheer grote invloed kan hebben op de waterkwaliteit, maar ook op de waterkwantiteit in het watersysteem. De indruk is dat agrarische grondgebruikers hier nauwelijks rekening mee houden bij de keuzes die ze maken, terwijl in veel gevallen de belangen niet botsen met de agrarische productiefunctie. Een voorbeeld is voldoende organische stof en een goede bodemstructuur, die in het belang zijn van de teelt, maar ook het waterbergend vermogen van de grond verhogen.

Vraag 2 belang achter het initiatief (wie)

Waterschap Noorderzijlvest is de belangrijkste initiatiefnemer.

Vraag 3 beoogde gebruikers en hun belang

De insteek is om belangen van het waterschap te verbinden aan het 'boerenbelang', in de trant van 'goed voor uzelf en goed voor het water'. Dit zou de bereidheid van grondgebruikers om de gewenste maatregelen te nemen, sterk kunnen verhogen.

Vraag 4 data behoefte en toegang

In eerste instantie gaat Trijntje van start met hoofdzakelijk kwalitatieve perceelsinformatie (zelfbeoordeling door de gebruiker van structuur, organische stof etc.). De ambitie is om uiteindelijk allerlei perceelsdata te ontsluiten en te koppelen, inclusief de meetdata van de waterbeheerder (zie Akkerweb). De data is eigendom van de perceelseigenaar, die anderen (adviseurs, huurders etc.) kan machtigen om deze data in te zien.

Vraag 5 status

In ontwikkeling (projectplan is gereed).

\subsubsection{Wel en Wee app}

Vraag 1 wat is het/wat doet het? Korte beschrijving. 
De Wel en Wee app is een applicatie van Akkerweb. Het combineert informatie verzameld met de mobiel met Akkerweb. Wanneer een teler of adviseur een afwijking constateert in het veld kan hij deze plek $x, y$ vastleggen en de constateringen opnemen op zijn mobiel eventueel aangevuld met een foto. Dit item kan hij delen met andere app gebruikers. De ontvanger kan met behulp van een ingebouwde routeplanner de plek terugvinden. Aanvullende informatie, zoals van een grond en gewasmonster, kan aan de $x, y$ coördinaten worden gekoppeld. Afhankelijk van de kwaliteit van het satellietsignaal kan dit tot op $2 \mathrm{~cm}$. nauwkeurig. De informatie verzameld met de wel en wee app ziet de teler terug op de tijdlijn van zijn perceel binnen de bouwplanmodule van akkerweb. Hij kan daar ook eerdere informatie zoeken. Op deze wijze houdt de teler grip op alles wat hij op zijn perceel gezien heeft en kan hij gemakkelijk informatie uitwisselen met collega's en adviseurs.

Vraag 2 belang achter het initiatief (wat, wie)

Praktijkonderzoek AGV is initiatiefnemer van deze app. Realisatie wordt mogelijk gemaakt van uit de PPS PL 2.0 en het Europese project Mycokey.

Vraag 3 beoogde gebruikers en hun belang

Telers en hun adviseurs. Actief gebruik maken van de informatie die in het veld groeit leidt tot vervroegde opsporing van bodemziekten maar ook van andere bodemproblemen. Door nauwkeurige vastlegging van de data wordt het bruikbare informatie die telers helpt om eerder te anticiperen op de ontwikkeling van bodemkwaliteitsproblemen.

Vraag 4 data behoefte en toegang

Geo-informatie die de gebruiker invoert (foto's, beschrijvende teksten) worden gekoppeld met perceelsinformatie op Akkerweb. Deze data zijn eigendom van de gebruiker en kunnen door hem gedeeld worden met derden.

Vraag 5 status

Eerste prototype beschikbaar. Definitieve versie eind september 2017

\subsection{Verantwoording}

\subsubsection{Bodempaspoort}

Vraag 1 wat is het/wat doet het? Korte beschrijving.

Informatie over bodemkwaliteit (analysegegevens, teelthistorie) beschikbaar maken bij grondtransacties (huur/pacht, koop). In het ZLTO gebied is er veel onduidelijkheid over de bodemkwaliteit bij grondtransacties, met name rond de contractteelt van industriegroenten. Hierdoor kan de bodemkwaliteit onvoldoende een rol spelen in de waardebepaling en geschiktheidsbeoordeling.

Vraag 2 belang achter het initiatief (wie)

Het initiatief achter het Bodempaspoort ligt bij ZLTO

Vraag 3 beoogde gebruikers en hun belang

Alle aanbieders van koop/pacht/huurgrond worden geacht een bodempaspoort te leveren bij het perceel wat te koop/pacht/huur wordt aangeboden. Voor aanbieders van goede grond is een bodempaspoort interessant, omdat het de waarde van de grond verhoogt. Voor percelen met een specifiek probleem kan het ertoe leiden dat de grond voor een goede prijs verkocht/verpacht/verhuurd kan worden voor een geschikte toepassing. Voor percelen met veel problemen leidt een bodempaspoort tot een potentiële waardedaling. Echter, als het bodempaspoort succesvol wordt, is het niet hebben van een bodempaspoort ook van negatieve invloed op de waarde. 
Vraag 4 data behoefte en toegang

Eigenaren en gebruikers kunnen online informatie van een perceel uploaden: perceelshistorie (wat is er de afgelopen jaren geteeld), beschikbare bodemanalyses en waarnemingen (zoals goede en slechte plekken, onkruidbestand). Er worden dus geen specifieke analyses vereist.

De eigenaar heeft toegang tot de data van een perceel en kan deze beschikbaar maken voor anderen, zoals huurders/pachters en (potentiële) kopers in de vorm van een bodempaspoort.

Vraag 5 status

Is beschikbaar voor de praktijk (m.n. in het ZLTO gebied?)

https://www.zlto.nl/bodempaspoort

\subsubsection{Boer \& Bunder}

Vraag 1 wat is het/ wat doet het? Korte beschrijving.

Boer \& Bunder is een applicatie die open data visualiseert op perceelsniveau. De app toont voor alle 1,9 miljoen hectare landbouwgrond in Nederland een aantal open datasets, zoals de perceelsinformatie van RvO (op basis van de jaarlijkse perceelsopgave), satellietbeelden, bodem- en hoogtekaarten.

Vraag 2 belang achter het initiatief (wie)

Boer \& Bunder is een initiatief van Hackwerk Advies, Liters, Boerenverstand en Dacom/Crop- $\mathrm{R}$ en is ontstaan in opvolging van de vele Agro en Food Hackatons. Het project is financieel mogelijk gemaakt door het Ministerie van Economische Zaken.

Vraag 3 beoogde gebruikers en hun belang

Volgens de website: Door data makkelijk beschikbaar te stellen en deelbaar te maken wil Boer \& Bunder de boer helpen om te communiceren over zijn bedrijf en resultaten waar hij trots op is. Uit de praktijk blijkt dat informatie van Boer \& Bunder veel wordt gebruikt door bedrijven die een perceel willen huren daarvoor de teelthistorie van het perceel checken.

Vraag 4 data behoefte en toegang

De perceelsdata komt o.a. uit perceelsopgaven van RvO en wordt vrij beschikbaar gesteld via Boer \& Bunder voor iedereen. Boeren kunnen zelf data toevoegen voor hun percelen.

Vraag 5 status

Online beschikbaar

www. boerenbunder.nl

\subsubsection{Label Duurzaam Bodembeheer}

Vraag 1 wat is het/wat doet het? Korte beschrijving.

Het is een label dat categoriseert hoe duurzaam de bodem beheerd wordt. Bij het voldoen aan bepaalde beheermaatregelen worden punten toegekend, dit puntenaantal valt binnen een bepaalde categorie en zo wordt de grond 'gelabeld'. Een agrariër die alle opgestelde maatregelen toepast komt zo in de hoogst haalbare categorie en krijgt hier bijvoorbeeld een beloning voor, of het zorgt er simpelweg voor dat de grond meer waard wordt.

Vraag 2 belang achter het initiatief (wat, wie)

Grond is voor ASR een beleggingsobject. Duurzaam bodembeheer is een belangrijke voorwaarde om de waarde van de grond te bewaken of zelfs te verhogen/versterken. ASR heeft CLM opdracht gegeven om maatregelen te formuleren en bijbehorende indicatoren die de uitvoer van de maatregelen controleren. Het label is tot stand gekomen met medewerking van Aequator, Eurofins Agro, NMI, NIOO, Louis Bolk Instituut, Wageningen University en Research en RIVM.

Vraag 3 beoogde gebruikers en hun belang 
Het Label zelf zal vooral door ASR gebruikt worden, voor de aandeelhouders. Boeren moeten de maatregelen toepassen en zelf aangeven welke (duurzame) beheersmaatregelen ze nemen. Het is verder de bedoeling dat andere terreinbeherende organisaties het label in gaan zetten in testpilots in 2017-2018. Betrokken partijen zijn vooralsnog o.a. Vitens en ASR.

Vraag 4 data behoefte en toegang

De gebruiker (pachter) voert zijn/haar beheersmaatregelen in. De certificerende instantie en de verpachter kunnen deze gegevens inzien.

Vraag 5 status

Is ontwikkeld, gaat nu pilotfase in.

http://www.clm.nl/uploads/pdf/910-CLMrapport-Ontwerp_Label_Duurzaam_Bodembeheer_(ASR).pdf

\subsubsection{Milieukeur maatregelen}

Vraag 1 wat is het/ wat doet het? Korte beschrijving.

Milieukeur is gebaseerd op een integrale benadering bij de verduurzaming van producten en diensten, met een gebalanceerde afweging tussen de verschillende duurzaamheidsthema's. De criteria van Milieukeur hebben daarbij betrekking op de hele levenscyclus van een product of dienst. Voor specifieke teelten ('open teelten', 'bedekte teelten', 'boomkwekerijgewassen', etc.) heeft Milieukeur certificeringscriteria ontwikkeld rond het thema bemesting, gewasbescherming, waterbeheer en bodembeheer). Afnemende ketenpartijen eisen het certificaat als voorwaarde (of kunnen dat doen). Certificaten zijn op teeltniveau.

Vraag 2 belang achter het initiatief (wie)

Stichting Milieukeur (SMK) heeft de certificatie opgezet en waakt zo over de duurzaamheid van onder andere productieketens.

Vraag 3 beoogde gebruikers en hun belang

Agrarische ondernemers vragen certificatie aan, en na toetsing (en als men voldoet aan voorwaarden) wordt het bedrijf gecertificeerd. Hiermee krijgen telers mogelijk een hogere prijs voor hun product, en ketenpartijen kunnen zich onderscheiden in de markt.

Vraag 4 data behoefte en toegang

Beschreven in criterialijsten per teelt op de website van milieukeur.nl. Database met gegevens beschikbaar bij SMK. Niet openbaar.

Vraag 5 status

Wordt actief gebruikt/ toegepast (voor sommige teelten door vrijwel alle ondernemers).

\subsubsection{Pachtvoorwaarden provincie $\mathrm{NH}$ - uitgifte van eigen pachtgrond onder duurzaamheidscertificering}

Vraag 1 wat is het/ wat doet het? Korte beschrijving.

De agrarische grond van de provincie Noord-Holland wordt verpacht aan agrarische gebruikers. Dit gebeurt bij inschrijving als een pachtcontract afloopt. Sinds 2016 hebben inschrijvers met een duurzaamheidscertificaat voorrang, zoals biologisch (EKO/SKAL), Caring Dairy, Milieukeur en Veldleeuwerik. Deze certificaten hebben allemaal aandacht voor bodem en diversiteit, maar zijn meestal breder.

Vraag 2 belang achter het initiatief (wie)

De provincie Noord-Holland is initiatiefnemer, om waarde van hun grond te behouden en verduurzaming te stimuleren. 
Vraag 3 beoogde gebruikers en hun belang

De pachters zijn als gebruiker van de provinciale pachtgronden de beoogde gebruikers. Hun primaire belang is de beschikbaarheid van deze gronden (zonder certificaat kom je minder snel in aanmerking). Vervolgens spelen er, afhankelijk van het certificaat, nog een aantal andere belangen, zoals een hogere prijs voor het product of toegang tot bepaalde ketens (biologisch, milieukeur). De verbetering van de bodemkwaliteit is ook in het belang van de pachter, maar waarschijnlijk zijn de meeste certificaten geen 'garantie' op een betere bodemkwaliteit.

Vraag 4 data behoefte en toegang

Overleggen van een certificaat bij inschrijving voor pachtgrond is voldoende. De verschillende certificaten vragen zelf ook de nodige data.

Vraag 5 status

Ingevoerd sinds 2016.

https: //www.noord-holland.nl/Loket/Onroerend_goed

\subsubsection{Veldleeuwerik Duurzaamheidsplan- bodemmaatregelen}

Vraag 1 wat is het/ wat doet het? Korte beschrijving.

Stichting Veldleeuwerik ontvangt een certificaat voor de verduurzamingssystematiek van Veldleeuwerik (VL) die is opgezet met deelnemende akkerbouwbedrijven. Het certificaat kan vervolgens worden afgegeven aan de deelnemende bedrijven, mits ze voldoen aan de systematiek. Dat betekent o.a. het opstellen en uitvoeren van een duurzaamheidsplan met een aantal zelfgekozen duurzaamheidsacties (gekoppeld aan de $10 \mathrm{VL}$ indicatoren) en het deelnemen aan een aantal regioen kennisbijeenkomsten. Het is dus geen prestatie-, maar een procescertificering. Bodem is een belangrijk thema voor akkerbouwers en is dus ook vertegenwoordigd in de 10 duurzaamheidsindicatoren.

Vraag 2 belang achter het initiatief (wie)

Stichting Veldleeuwerik

Vraag 3 beoogde gebruikers en hun belang

Akkerbouwers borgen met behulp van Veldleeuwerik hun verduurzamingsproces en kunnen onderling kennis delen.

Vraag 4 data behoefte en toegang

Ingevuld duurzaamheidsplan (online) en deelname aan VL activiteiten. Deze data per deelnemer zijn niet openbaar, maar St. Veldleeuwerik communiceert wel overzichten (welke duurzaamheidsmaatregelen worden door hoeveel telers genomen).

Vraag 5 status

St. Veldleeuwerik is gecertificeerd sinds 2015. Bijna 400 akkerbouwers zijn aangesloten.

http://veldleeuwerik.nl/veldleeuwerik/de-werkwijze/veldleeuwerikcertificaat/

\subsection{Overige initiatieven}

Dat duurzaam bodembeheer een actueel thema is, blijkt ook uit de veelheid aan initiatieven en projecten op dit vlak.

\subsubsection{SoilCares}

Een internationaal gericht initiatief is Soilcares: hierbij worden instrumenten ontwikkeld/beschikbaar gesteld om overal ter wereld snel en kosteneffectief bodemanalyses te kunnen doen en advies te kunnen geven. Services die momenteel aangeboden worden zijn een bodemscanner (in het veld 
binnen 10 min een bodemkwaliteitscheck), de scoutbox (lokaliseert, telt en determineert insecten) en een lab-in-a-box (vrij complete set laboratorium instrumenten om bodemanalyses te doen). In Nederland zijn betrouwbare systemen die relatief kosteneffectief zijn, maar er wordt wel overwogen om een Nederlandse versie te ontwikkelen (met HLB als Nederlandse partner).

\subsubsection{Soil Health Index}

Zo wordt op initiatief van Wageningen Environmental Research nagegaan of de Soil Health Index (https://soilhealth.cals.cornell.edu/), ontwikkeld door Cornell University, vertaald kan worden naar de Nederlandse context. De index geeft inzicht in de status van de bodem, met gebruik van de bodemanalyse data en een self-assessment. De index bevat bepaalde streefwaarden waar waargenomen waarden aan kunnen worden getoetst, en zo kan de status van de bodem worden bepaald. Wanneer dit initiatief in Nederland in de praktijk toepasbaar zal zijn is nog niet bekend.

\subsubsection{Diverse onderzoekstools}

De afgelopen jaren zijn er ook diverse initiatieven geweest om onderzoeksinstrumenten geschikt te maken voor gebruik in de praktijk, o.a. Nutmatch, een wiskundige rekenmodule van Wageningen Plant Research waarmee economisch optimale bemestingsplannen berekend kunnen worden voor rotaties van open teelt bedrijven, rekening houdend met effecten op de bodemvruchtbaarheid op korte en lange termijn, het Gebruiksnormenstelsel en bedrijfseconomie. Momenteel werkt Wageningen Environmental Research aan de vertaling van een bemestingstool naar de praktijk. 


\section{$4 \quad$ Analyse en Reflectie}

\subsection{Analyse}

In deze paragraaf wordt een analyse gegeven van alle instrumenten die in hoofdstuk 3 worden beschreven. Daarvoor is mede gebruik gemaakt van de discussie tijdens de themadag 'Beter bodembeheer - de diepte in' op 6 april 2017. Op die dag is een overzicht van de instrumenten gepresenteerd en besproken met een groep adviseurs, akkerbouwers, onderzoekers, docenten en beleidsmedewerkers.

\section{Er worden veel instrumenten ontwikkeld, maar het gebruik is beperkt}

Uit hoofdstuk 3 blijkt dat er veel instrumenten zijn en worden ontwikkeld. De meeste instrumenten richten zich op het meten/monitoren van bodemkwaliteit en/of op advies en beslissingsondersteuning voor de gebruiker voor het verbeteren van de bodemkwaliteit. Daarnaast is een relatief nieuwe categorie van instrumenten ontstaan die zich richt op het verantwoorden van het bodembeheer. Tijdens een discussie op de themadag 'Beter bodembeheer - de diepte in' op 6 april 2017 werd het aantal instrumenten positief gewaardeerd door de aanwezigen. Tegelijk bleek ook dat het gebruik op dit moment beperkt is: het beeld is dat de huidige tools beperkt worden gebruikt door een kleine groep gebruikers, en dan met name adviseurs.

\section{Er is geen regie}

Er is geen regie op de ontwikkeling van de instrumenten en er lijkt ook geen partij in de positie om deze regie te nemen. De enige partij die regelmatig werd genoemd is de Brancheorganisatie Akkerbouw, maar die verkeert momenteel in een lastige fase. Enkele initiatieven ontwikkelen zich wel tot een platform voor data en applicaties, zoals Mijnpercelen en Akkerweb.

\section{Onderdeel van commerciële dienstverlening of resultaat van een project}

De indruk is dat de gebruikers voor de meeste instrumenten niet rechtstreeks betalen voor het gebruik: veel instrumenten zijn onderdeel van de dienstverlening van een (advies) organisatie aan klanten en zijn ook voor dat doel ontwikkeld. Andere instrumenten zijn ontwikkeld in een project en worden vervolgens online beschikbaar gesteld, zoals NDICEA of de daarop gebaseerde mineralisatietool op Kennisakker. In deze categorie is het onderhoud na afloop van het project wel een zorgpunt: soms lukt het om (project)middelen te vinden voor doorontwikkeling (NDICEA in het verleden), soms lukt dat niet (tool op Kennisakker).

\section{Onderbouwing}

Bij de meeste instrumenten is onduidelijk wat de onderliggende rekenregels en data zijn, waardoor het ook niet helder is of de (wetenschappelijke) basis van de instrumenten solide is. Zeker als instrumenten gekoppeld zijn aan commerciële advisering, is transparantie hierover gewenst. Nutrinorm (ontwikkeld in opdracht van $\mathrm{OCl}$ ) geeft het goede voorbeeld van deze transparantie.

\section{I ntegraliteit}

Met integraliteit wordt bedoeld of het instrument gericht is op de bodemkwaliteit in de breedte. Dus zowel op bodemstructuur, chemische bodemvruchtbaarheid als bodemleven, of slechts op één of twee van deze componenten. Al deze drie componenten zijn in de bodem met elkaar verbonden en interacteren met elkaar. Een instrument dat dit erkent en niet slechts één van de componenten benadert, maar een integrale aanpak heeft, verdient daarom de voorkeur.

In Figuur 4.1 worden alle instrumenten weergegeven op basis van hun integraliteit. Pachtvoorwaarden Noord-Holland is buiten de driehoek geplaatst, omdat dit instrument gebruik maakt van allerlei andere instrumenten/certificeringen om tot een oordeel over verantwoord bodemgebruik te komen. 


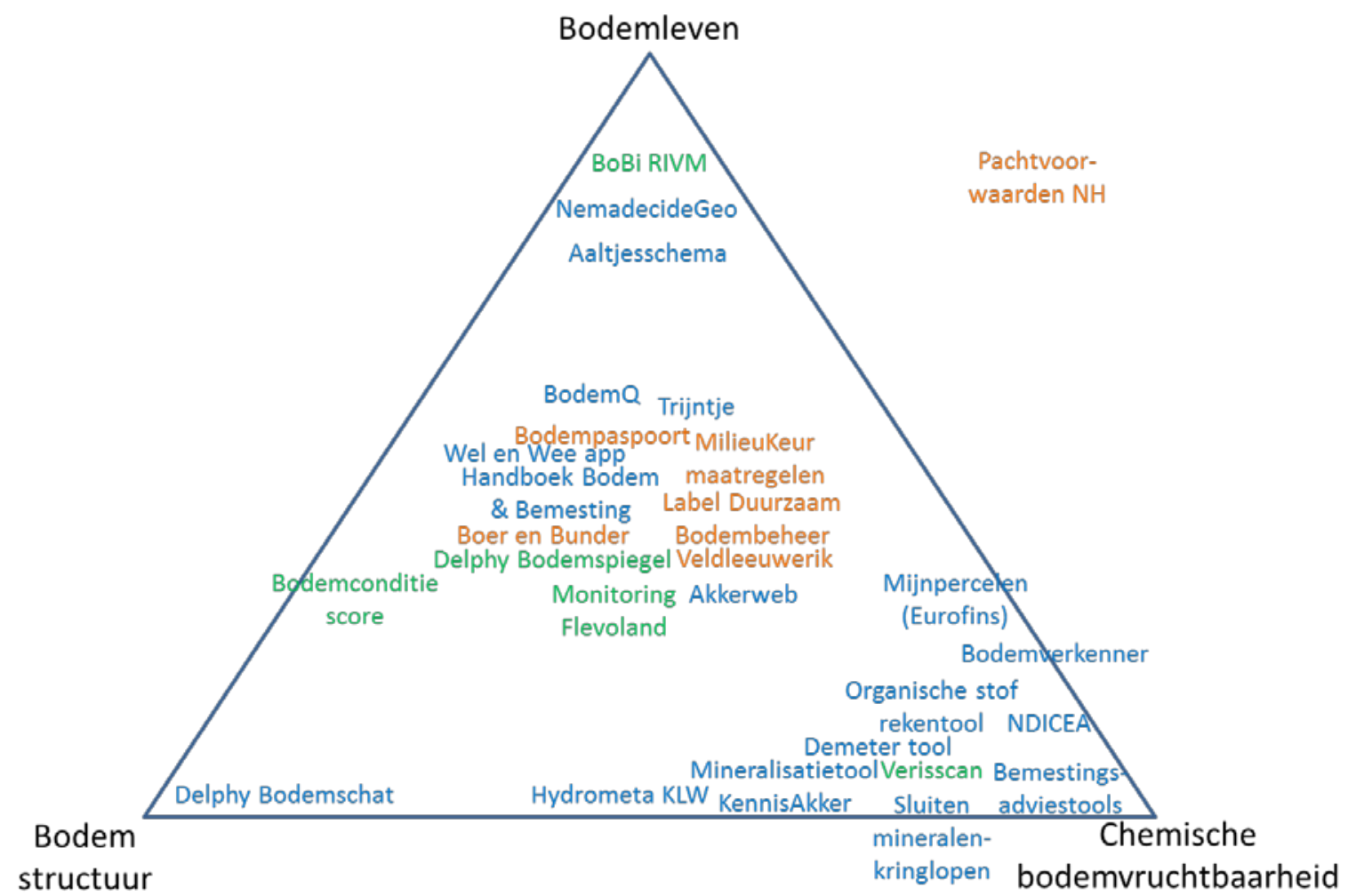

Figuur 4.1. Overzicht van integraliteit van bodemkwaliteitsinstrumenten. Kleuren geven de functionaliteit van de instrumenten weer; groen = meten, blauw = monitoring en advies, oranje = verantwoording. De diverse bemestingstools zijn niet individueel weergegeven vanwege de leesbaarheid en omdat deze grotendeels dezelfde werkwijze hebben. Hieronder vallen 5 tools: Delphy bemestingsplan, DLV mijNperceel.nl, Mest en Mineraal (Agrifirm), Nutrinorm bemestingsplanner en Slim Bemesten.

Wat opvalt is het cluster rechtsonder (chemische bodemvruchtbaarheid) en het cluster in het midden (integraal). De focus op bodemvruchtbaarheid is goed verklaarbaar, niet alleen omdat het rechtstreeks de gewasproductie beïnvloedt: het optimaliseren van de bemesting binnen de wettelijke kaders is een belangrijke en complexe opgave voor akkerbouwers en veehouders. Diverse tools helpen de boer en zijn adviseur om betere keuzes te maken in deze ingewikkelde meervoudige optimalisatie: sommige instrumenten presenteren analysedata op een overzichtelijke manier (mijnpercelen), andere instrumenten voorspellen de bodemmineralisatie in het seizoen en daarnaast zijn er diverse tools die concrete bemestingsadviezen geven op perceels- en bedrijfsniveau.

Het cluster van integrale tools is lastiger verklaarbaar: het is mogelijk een reflectie van de toenemende erkenning dat een eenzijdige benadering (vooral gericht op bodemvruchtbaarheid) te smal is om tot goed bodembeheer te komen. Het is in dat opzicht interessant om te zien dat de meeste verantwoordingstools een integrale benadering hebben. De integrale adviestools vormen nog een kleine categorie, vergeleken met de adviestools die m.n. gericht zijn op chemische bodemvruchtbaarheid.

Bij de instrumenten gericht op bodemleven valt op dat sommige instrumenten zich sterk richten op het schadelijke bodemleven (zoals NemaDecide), terwijl andere instrumenten zich vooral op het 'positieve' bodemleven richten als indicatie voor de bodemkwaliteit (Bobi en in mindere mate ook de bodemconditiescore die zich qua bodemleven alleen richt op wormen en niet op zichtbare aaltjesschade).

Bodemstructuur is een belangrijk aandachtspunt in de praktijk, maar is moeilijk kwantificeerbaar via routinematige analyses. Dit verklaart waarschijnlijk waarom weinig instrumenten zich met bodemstructuur bezighouden.

\section{Welke bodemdata worden gebruikt?}

Figuur 4.2 geeft eenzelfde overzicht van de instrumenten, maar dan op basis van het datagebruik van het instrument. Hierin wordt onderscheid gemaakt in drie categorieën: default data, zelf gemeten data 
en lab analyses. Met default data wordt gedoeld op bijvoorbeeld referentiewaarden gebaseerd op regio- of grondsoort.

Wat opvalt in Figuur 4.2 is dat relatief veel instrumenten uitgaan van default data, niet van bedrijfseigen perceelsspecifieke data. Het voordeel is dat er niets gemeten of ingevoerd hoeft te worden, maar de resultaten zijn minder nauwkeurig en houden geen rekening met de bedrijfs- en perceelsspecifieke situatie.

Een aantal instrumenten richt zich uitsluitend op het ondersteunen van eigen waarnemingen, ofwel visueel (Bodemconditiescore) of via sensoren (Verisscan, Delphy Bodemspiegel). Andere instrumenten richten zich uitsluitend op analyses door laboratoria en gebruiken deze gegevens als input.

Andere instrumenten combineren verschillende databronnen, zoals de tools rond de Kringloopwijzer, die lab-analyses, default data en eigen metingen/schattingen naast elkaar gebruiken. 3 instrumenten staan buiten de driehoek, omdat in de werking van deze instrumenten geen specifieke data meegenomen wordt, deze tools geven algemene richtlijnen.

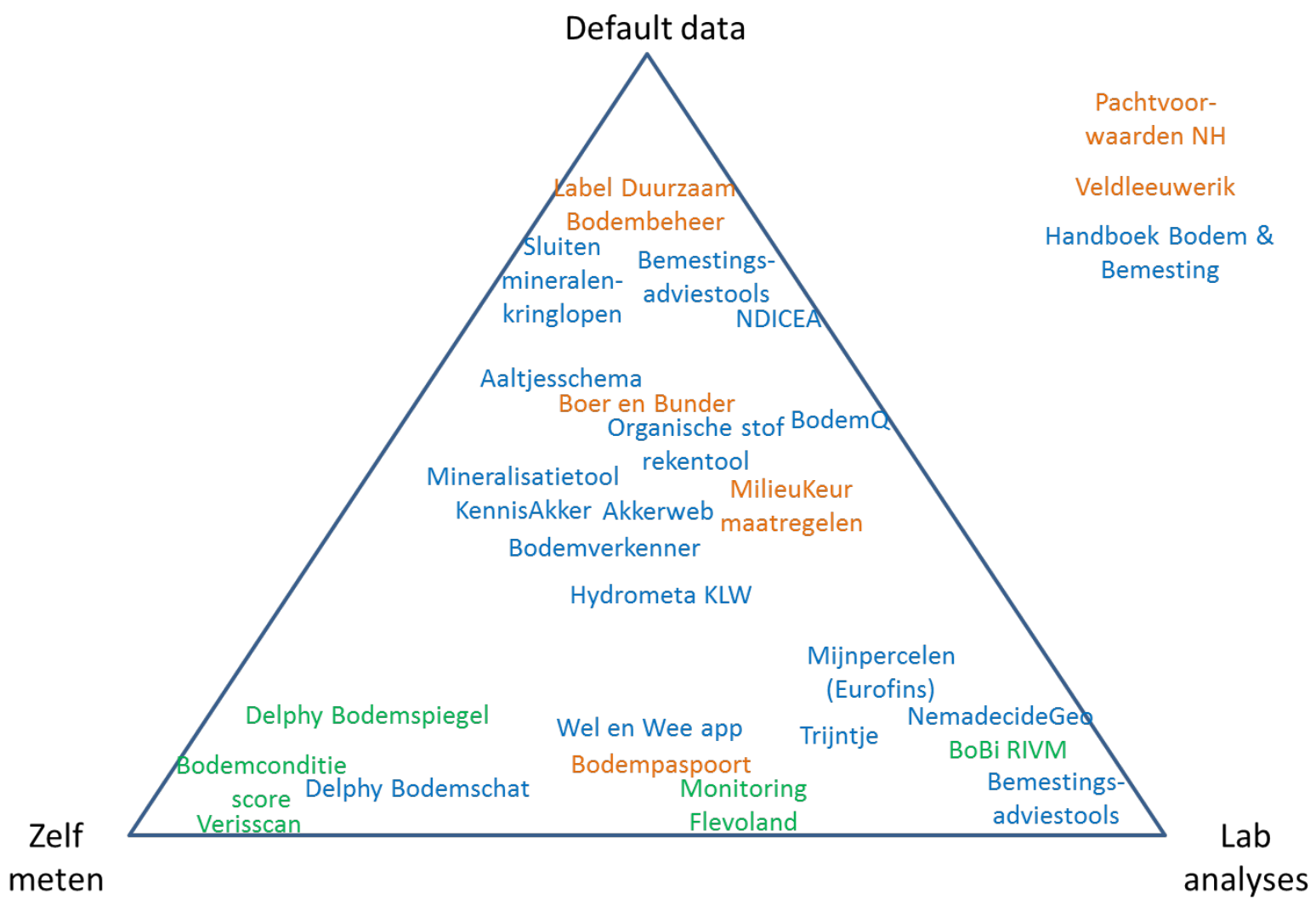

Figuur 4.2. Overzicht van datagebruik van bodemkwaliteitsinstrumenten. Kleuren geven de functionaliteit van de instrumenten weer; groen = meten, blauw = monitoring en advies, oranje = verantwoording. De bemestingstools zijn niet individueel weergegeven, omdat deze grotendeels dezelfde werkwijze hebben en het de leesbaarheid van de figuur niet ten goede zou komen. Hieronder vallen 5 tools: Delphy bemestingsplan, DLV mijNperceel. nl, Mest en Mineraal (Agrifirm), Nutrinorm bemestingsplanner en Slim Bemesten.

\section{Bereik van de instrumenten}

De instrumenten hebben een verschillend doelbereik: ze richten zich op de akkerbouw of de melkveehouderij en ze hebben een regionale afbakening of ze worden landelijk ingezet.

Het valt op in Figuur 4.3 dat er relatief veel instrumenten exclusief voor de akkerbouw worden ontwikkeld (bovenin), dat ook een relatief groot aantal voor beide sectoren is ontwikkeld (midden) en slechts enkele zich specifiek richten op de melkveehouderij. Dat reflecteert mogelijk ook de het verschil in aandacht voor bodembeheer in de praktijk van beide sectoren: op een deel van de 
melkveebedrijven concentreert de veehouder zich vooral op de dieren en nauwelijks op het 'buitenwerk'. De aandacht voor het bodembeheer in de veehouderij neemt wel toe, vooral bodemstructuur staat hoger op de agenda.

De regionale insteek van een aantal instrumenten is begrijpelijk vanuit het exclusief regionale belang (Flevoland en Noord-Holland). Andere instrumenten zijn ontwikkeld vanuit een regionaal initiatief, maar zijn in principe ook bruikbaar buiten deze regio (Bodempaspoort, sluiten mineralenkringlopen).

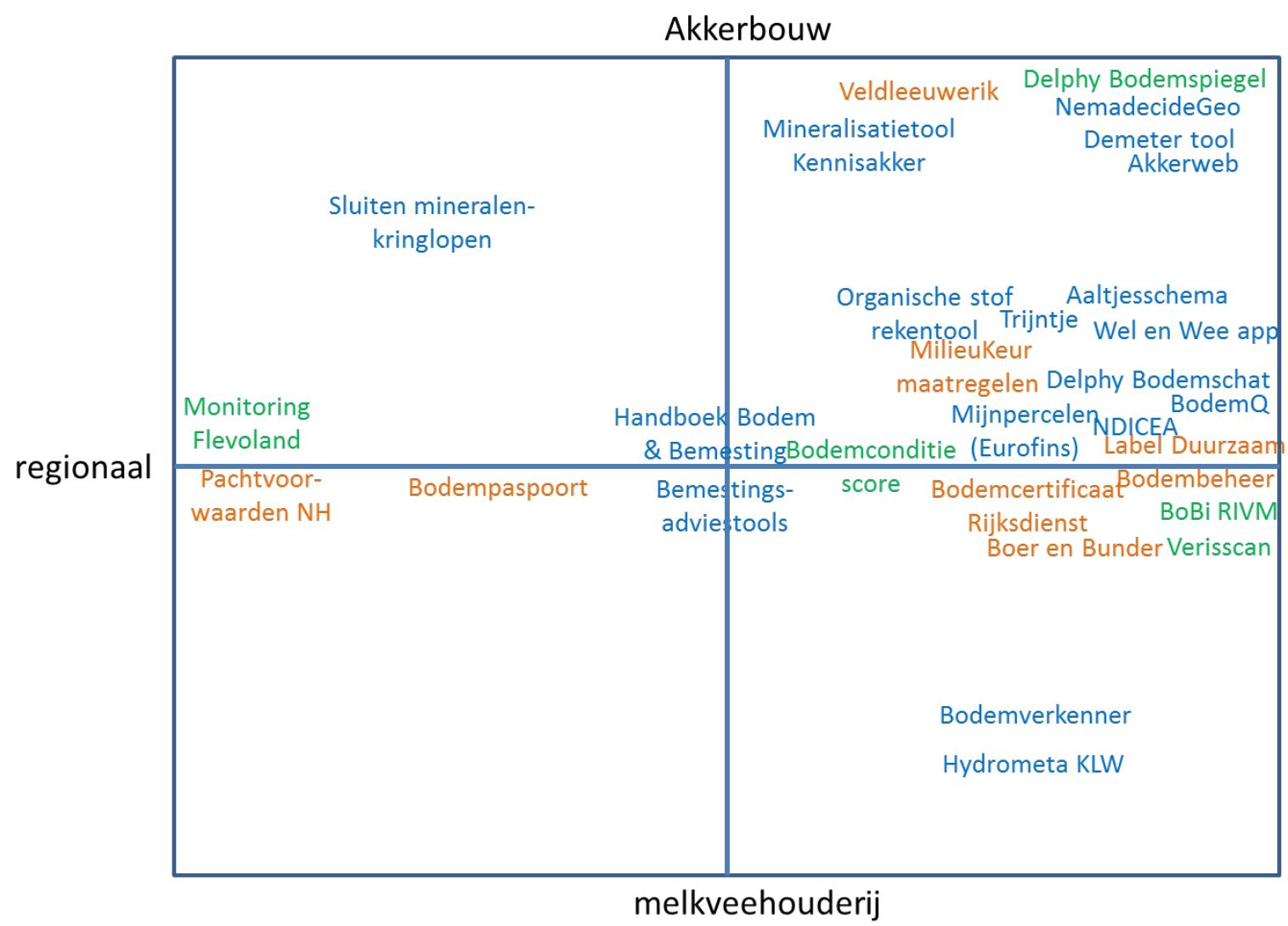

landelijk

Figuur 4.3. Overzicht van het bereik van bodemkwaliteitsinstrumenten. Kleuren geven de functionaliteit van de instrumenten weer; groen = meten, blauw = monitoring en advies, oranje = verantwoording. De bemestingstools zijn niet individueel weergegeven, omdat deze grotendeels dezelfde werkwijze hebben en het de leesbaarheid van de figuur niet ten goede zou komen. Hieronder vallen 5 tools: Delphy bemestingsplan, DLV mijNperceel.nl, Mest en Mineraal (Agrifirm), Nutrinorm bemestingsplanner en Slim Bemesten. 


\subsection{Reflectie}

Uit de themadag 'Beter bodembeheer - de diepte in' op 6 april 2017 komen nog drie reflecties naar voren die in feite een aanbeveling vormen voor iedereen die betrokken is bij de ontwikkeling van instrumenten voor duurzaam bodembeheer.

\section{Gebruik bedrijfseigen perceelsspecifieke data}

De instrumenten die 'real data' gebruiken in plaats van 'default data' hebben de toekomst: het wordt steeds eenvoudiger om gebruik te maken van bedrijfseigen data, bijvoorbeeld via platforms als Mijnpercelen of Akkerweb. Daarmee is het advies veel beter toegesneden op de bedrijfs- en perceelsspecifieke situatie.

\section{Werk aan integratie van instrumenten}

Veel instrumenten vragen dezelfde basisinformatie over bodem, perceel en bedrijf als input. Als gebruikers meerdere instrumenten naast elkaar gebruiken kost het veel tijd om deze gegevens steeds weer in te voeren, het vergroot ook de kans op fouten. Door integratie van instrumenten aan de invoerkant, bijvoorbeeld door ze te koppelen aan één dataplatform, kan veel worden opgelost. Echter, het is ook mogelijk dat losse instrumenten dan nog tot tegengestelde adviezen komen. Om dat te voorkomen of op z'n minst zichtbaar te maken, is integratie aan de achterkant ook wenselijk. De gebruiker kan dan bijvoorbeeld de melding krijgen dat een groenbemester mogelijk erg geschikt is nutriënten vast te houden, maar wel een risico geeft op de vermeerdering van aaltjes.

\section{Werk aan kennis van de gebruiker}

Op de themadag 'Beter bodembeheer - de diepte in' op 6 april 2017 werd ook duidelijk dat naast de ontwikkeling van de instrumenten ('smart farming') de gebruiker niet vergeten moet worden: Smart Farming vraagt ook Smart farmers en Smart Advisors. Zonder de nodige kennis van de bodem (algemene kennis en kennis van het eigen bedrijf) is het erg lastig om de instrumenten goed te gebruiken. Hier ligt een opgave voor het onderwijs, maar ook voor adviespartijen en zeker ook voor akkerbouwers en melkveehouders (individueel en collectief). Er zijn voorbeelden waarin bedrijven nieuwe buitendienstmedewerkers standaard op een cursus sturen om een adviesinstrument goed te kunnen gebruiken.

\section{Nabije toekomst}

Eén van de doelen van dit rapport is dat het lezers helpt de weg te vinden naar de instrumenten die voor hen meerwaarde bieden. De verwachting is dat ook op bodemgebied er in hoog tempo meer applicaties beschikbaar komen, variërend van een eenvoudige één-vraag één-antwoord app tot de integrale DSS toegesneden op perceelsniveau. Dit rapport kan ontwikkelaars en aanbieders helpen om hun instrumenten goed te positioneren, samenwerking te zoeken en losse tools beter te integreren.

Daarnaast roepen we alle betrokkenen op om aandacht te besteden aan de benodigde kennis van gebruikers, zodat instrumenten effectief gebruikt kunnen worden om het bodembeheer te verbeteren. Daar ligt wat ons betreft een gezamenlijke verantwoordelijkheid van overheid, sector en bedrijfsleven: door regievoering kunnen middelen voor ontwikkeling van instrumenten effectiever worden ingezet en in combinatie met kennisontwikkeling bij gebruikers kunnen ontwikkelde instrumenten beter en sneller worden toegepast. 


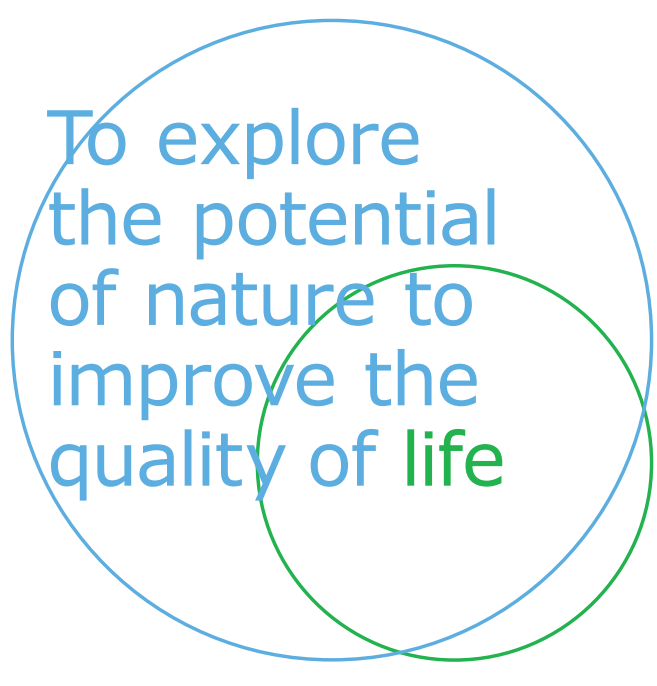

Contact | Leendert.molendijk@wur.nI

Wageningen University \& Research | Open Teelten Edelhertweg 1

Postbus 430

8200 AK Lelystad

T (+31)3202911 11

www.wur.nl/openteelten

Rapport WPR-740

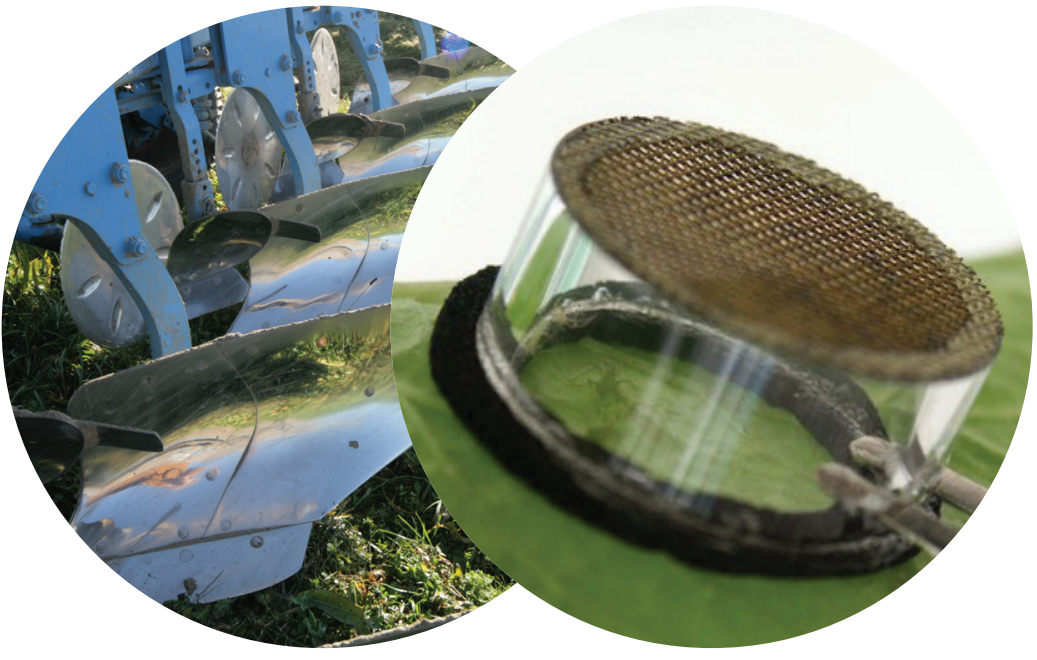

De missie van Wageningen University \& Research is 'To explore the potential of nature to improve the quality of life'. Binnen Wageningen University \& Research bundelen 9 gespecialiseerde onderzoeksinstituten van stichting DLO en Wageningen University hun krachten om bij te dragen aan de oplossing van belangrijke vragen in het domein van gezonde voeding en leefomgeving. Met ongeveer 30 vestigingen, 6.000 medewerkers en 9.000 studenten behoort Wageningen University \& Research wereldwijd tot de aansprekende kennisinstellingen binnen haar domein. De integrale benadering van de vraagstukken en de samenwerking tussen verschillende disciplines vormen het hart van de unieke Wageningen aanpak. 